University of Wollongong

Research Online

Faculty of Engineering and Information

Faculty of Engineering and Information

Sciences - Papers: Part A

Sciences

$1-1-2015$

\title{
Effects of iron salt addition on biosolids reduction by oxic-settling-anoxic (OSA) process
}

\author{
Galilee U. Semblante \\ University of Wollongong, gus193@uowmail.edu.au \\ Faisal I. Hai \\ University of Wollongong, faisal@uow.edu.au \\ Heriberto Bustamante \\ Sydney Water Corporation \\ Nelly Guevara \\ Sydney Water Corporation \\ William E. Price \\ University of Wollongong, wprice@uow.edu.au
}

See next page for additional authors

Follow this and additional works at: https://ro.uow.edu.au/eispapers

Part of the Engineering Commons, and the Science and Technology Studies Commons

\footnotetext{
Research Online is the open access institutional repository for the University of Wollongong. For further information
} contact the UOW Library: research-pubs@uow.edu.au 


\title{
Effects of iron salt addition on biosolids reduction by oxic-settling-anoxic (OSA) process
}

\author{
Abstract \\ The oxic-settling anoxic (OSA) process interchanges activated sludge between alternating redox \\ conditions (e.g., aerobic and anoxic) to reduce biosolids production. Iron salts addition to wastewater is \\ performed to remove phosphorous, but this study demonstrated that it may impair OSA performance. \\ Batch test results showed that the addition of iron salt (as Fe2+) decreased the volatile solids reduction \\ of an intermittently aerated batch reactor (i.e., aerobic/anoxic), probably because iron reduced the \\ destruction of extracellular polymeric substances (EPS) that serve as the structural framework of sludge \\ flocs. The effect of different FeCl2 dosages $(0,15$, and $30 \mathrm{mg} \mathrm{I}-1)$ on the sludge yield and EPS profile of \\ an OSA system consisting of a sequencing batch reactor (SBR) attached to external aerobic/anoxic and \\ anoxic reactors was compared to those of a control system consisting of an SBR attached to a single- \\ pass aerobic digester. The two SBRs were fed with real wastewater and operated continuously in parallel \\ for $230 \mathrm{~d}$. Without FeCl2 addition, the sludge yield (g MLVSS g-1 COD) of the SBR in the OSA system was \\ $24.8 \%$ less than that of the control SBR. Moreover, the waste sludge of the OSA system had lower volatile \\ solids content than that of the control system. When 15 or $30 \mathrm{mg} \mathrm{l}-1 \mathrm{FeCl} 2$ was added to the influent, \\ OSA was unable to decrease the sludge yield of the SBR and the volatile solids content of the waste \\ sludge. $\mathrm{FeCl} 2$ dosing increased the EPS concentration of sludge in the external aerobic/anoxic reactor, \\ confirming that floc destruction in that reactor was reduced by the presence of iron.

\section{Disciplines} \\ Engineering | Science and Technology Studies

\section{Publication Details} \\ Semblante, G. U., Hai, F. I., Bustamante, H., Guevara, N., Price, W. E. \& Nghiem, L. D. (2015). Effects of iron \\ salt addition on biosolids reduction by oxic-settling-anoxic (OSA) process. International Biodeterioration \\ and Biodegradation, 104 391-400.
}

\section{Authors}

Galilee U. Semblante, Faisal I. Hai, Heriberto Bustamante, Nelly Guevara, William E. Price, and Long D. Nghiem 
Effects of iron salt addition on biosolids reduction by oxic-settling-anoxic (OSA) process

\section{Accepted manuscript \\ International Biodeterioration \& Biodegradation}

Volume 104, October 2015, Pages 391-400

Galilee U. Semblante ${ }^{\mathrm{a}}$, Faisal I. Hai ${ }^{\mathrm{a}}{ }^{*}$, Heriberto Bustamante ${ }^{\mathrm{b}}$, Nelly Guevara ${ }^{\mathrm{b}}$, William E. Price ${ }^{c}$, and Long D. Nghiem ${ }^{a}$

${ }^{a}$ Strategic Water Infrastructure Laboratory, School of Civil, Mining and Environmental Engineering, University of Wollongong, Wollongong, NSW 2522, Australia

${ }^{\mathrm{b}}$ Sydney Water Corporation, Parramatta, NSW 2124, Australia

${ }^{c}$ Strategic Water Infrastructure Laboratory, School of Chemistry, University of Wollongong, Wollongong, NSW 2522, Australia

* Corresponding author:

Email: faisal@uow.edu.au, Ph: +61 242213054

Abstract: The oxic-settling anoxic (OSA) process interchanges activated sludge between alternating redox conditions (e.g. aerobic and anoxic) to reduce biosolids production. Iron 
salts addition to wastewater is performed to remove phosphorous, but this study demonstrated that it may impair OSA performance. Batch test results showed that the addition of iron salt (as $\mathrm{Fe}^{2+}$ ) decreased the volatile solids reduction of an intermittently aerated batch reactor (i.e., aerobic/anoxic), probably because iron reduced the destruction of extracellular polymeric substances (EPS) that serve as the structural framework of sludge flocs. The effect of different $\mathrm{FeCl}_{2}$ dosages $\left(0,15\right.$, and $\left.30 \mathrm{mg} \mathrm{l}^{-1}\right)$ on the sludge yield and EPS profile of an OSA system consisting of a sequencing batch reactor (SBR) attached to external aerobic/anoxic and anoxic reactors was compared to those of a control system consisting of an SBR attached to a single-pass aerobic digester. The two SBRs were fed with real wastewater and operated continuously in parallel for $230 \mathrm{~d}$. Without $\mathrm{FeCl}_{2}$ addition, the sludge yield (g MLVSS g ${ }^{-1}$ COD) of the SBR in the OSA system was $24.8 \%$ less than that of the control SBR. Moreover, the waste sludge of the OSA system had lower volatile solids content than that of the control system. When 15 or $30 \mathrm{mg}^{-1} \mathrm{FeCl}_{2}$ was added to the influent, OSA was unable to decrease the sludge yield of the SBR and the volatile solids content of the waste sludge. $\mathrm{FeCl}_{2}$ dosing increased the EPS of sludge in the external aerobic/anoxic reactor, confirming that floc destruction in that reactor was reduced by the presence of iron.

Keywords: extracellular polymeric substances; ferrous chloride; oxic-settling-anoxic (OSA); sludge reduction; soluble microbial products.

\section{Introduction}

Sludge treatment and disposal constitutes a significant portion of wastewater treatment plant (WWTP) operation cost. The decreasing availability of disposal options (e.g., landfilling and incineration) has triggered a renewed research interest to minimise biosolids production during wastewater treatment. The oxic-settling-anoxic (OSA) process exposes biomass in alternating redox conditions by treating a portion of activated sludge in an external anoxic reactor and then returning it to the main aerobic reactor (Semblante et al., 2014; Semblante et al., 2015). Despite several full-scale OSA installations (Coma et al., 2013; Foladori et al. 2015), there remains some contention regarding the mechanism/s responsible for sludge reduction in OSA. Chon et al. (2011a) hypothesized that oxygen- and substrate-deficient conditions in the external reactor enhance the disintegration of the extracellular polymer substances (EPS), which are proteins, carbohydrates, and other macromolecules that serve as the structural framework of sludge flocs. Other researchers proposed that OSA enables 'metabolic uncoupling' and forces microorganisms to select energy replenishment over cellular propagation (Chudoba et al., 1992), or that it transforms the ecology of activated sludge such that slow-growing bacteria or bacteriovores are enriched (Chudoba et al., 1992; Ye et al., 2008; Navaratna et al., 2014). However, none of these mechanisms have been validated through investigations conducted with real wastewater. The maximum sludge reduction achieved by full-scale OSA (e.g. 18\%) (Troiani et al., 2011; Coma et al., 2013) is significantly lower than those of laboratory-scale implementations (e.g. 58\%) fed with synthetic wastewater (Chudoba et al., 1992; Saby et al., 2003; Chon et al., 2011a), which warrants further investigation using real wastewater.

The role of iron in the flocculation (Higgins and Novak, 1997) and floc destruction under anaerobic conditions (Novak et al., 2003) has been reported, but its impact on OSA performance has not been systematically studied. Iron salts are commonly added to wastewater in full-scale plants for phosphorous removal by chemical process (Paul et al., 2001; An et al., 2014). When Fe(II) salt is added to an aerobic reactor, iron is spontaneously oxidised to $\mathrm{Fe}(\mathrm{III})$ given the availability of oxygen in the system (i.e., $2 \mathrm{Fe}^{2+}+2 \mathrm{H}^{+}+$ $1 / 2 \mathrm{O}_{2} \rightarrow 2 \mathrm{Fe}^{3+}+2 \mathrm{H}_{2} \mathrm{O}, \mathrm{E}_{\text {cell }}^{\circ}=+2.0 \mathrm{~V}$ ). Fe(III) forms hydroxyl complexes that serve as 'ion 
bridges' between negatively-charged sites of EPS and causes flocculation (Higgins and Novak, 1997). The binding of Fe(III) to EPS appears to make sludge flocs less easily dispersed or destroyed. For example, Niu et al. (2013) observed that the addition of $\mathrm{FeCl}_{3}(5-$ $10 \mathrm{~g} \mathrm{~g}^{-1}$ dry solids) prevented the destruction of flocs by shear stress. Mishima and Nakajima (2009) also observed that the addition of $\mathrm{FeCl}_{3}\left(2,000-5,000 \mathrm{mg} \mathrm{l}^{-1}\right)$ decreased the release of EPS into the supernatant of a membrane bioreactor.

The oxidation reduction potential (ORP) of the external reactor of OSA is a key parameter that impacts sludge reduction. Saby et al. (2003) observed that decreasing the ORP of the external reactor from $+100 \mathrm{mV}$ to less than $-250 \mathrm{mV}$ increased sludge reduction in a laboratory-scale OSA from 23 to 58\%. However, very low ORP levels are difficult to achieve under specific operational constraints, e.g., at low hydraulic retention time (HRT) (Saby et al., 2003; Troiani et al., 2011). Troiani et al. (2011) showed that treating sludge in alternating anaerobic $(\mathrm{ORP}=-400$ to $-200 \mathrm{mV})$ and anoxic ranges $(\mathrm{ORP}=-200$ to $+50 \mathrm{mV})$ in a fullscale plant resulted in sludge reduction of $13-17 \%$. In a full-scale plant, maintaining an ORP range is more practical than trying to maintain a specific ORP value. In this context, an OSA containing both aerobic and anoxic stages in the external reactor rather than a strictly anaerobic reactor may be additionally beneficial in terms of minimising the influx of soluble chemical oxygen demand (COD) and nutrients in the main bioreactor upon recirculation of treated sludge. Thus it is worthwhile to investigate the performance of an OSA containing both aerobic and anoxic stages in the external reactor, which has not been reported in literature.

This study investigates sludge reduction of an OSA system consisting of external aerobic/anoxic and anoxic reactors attached with an SBR receiving real wastewater. In addition, it determines the impact of $\mathrm{FeCl}_{2}$ addition on OSA performance. Preliminary batch tests were performed to investigate the effect of $\mathrm{FeCl}_{2}$ addition on volatile solids reduction under alternating redox conditions. Then, the effect of $\mathrm{FeCl}_{2}$ dosing on sludge reduction by the OSA system was assessed relative to a control system consisting of an SBR attached to a single-pass aerobic digester. The use of real wastewater in this study is critical in that although real wastewater can undergo significant temporal variations, it produces more realistic biomass growth rates and sludge properties. The sludge yield, volatile solids reduction, and EPS concentrations of the reactors were monitored.

\section{Materials and methods}

\subsection{Batch experiments}

A series of preliminary batch experiments were conducted to assess sludge reduction under two redox regimes, i.e. aerobic/anoxic and anoxic. Batch aerobic/anoxic reactors with and without a single addition of $30 \mathrm{mg} \mathrm{l}^{-1} \mathrm{FeCl}_{2}$ were aerated in intermittent mode (e.g., 8/16 hours aeration on/off) using an air diffuser placed at the bottom of the tank. Batch anoxic reactors with and without a single addition of $30 \mathrm{mg} \mathrm{l}^{-1} \mathrm{FeCl}_{2}$ were completely sealed with a silicone-lined cap equipped with a sampling port and a gas outlet port with an air trap to prevent air leakage. All reactors were kept in a $25{ }^{\circ} \mathrm{C}$ water bath, and continuously mixed by a magnetic stirrer.

The batch reactors were inoculated with activated sludge from the aerobic reactor of Wollongong WWTP. The sludge was centrifuged for $10 \mathrm{~min}$ at $3,267 \mathrm{xg}$, and then reconstituted in synthetic wastewater to make up a total volume of 21 . Synthetic wastewater representing medium-strength wastewater was used only in the batch experiments to study the impact of $\mathrm{FeCl}_{2}$ on volatile solids reduction. It was composed of glucose $\left(400 \mathrm{mg} \mathrm{l}^{-1}\right)$, 
peptone $\left(100 \mathrm{mg} \mathrm{l}^{-1}\right)$, urea $\left(35 \mathrm{mg} \mathrm{l}^{-1}\right), \mathrm{KH}_{2} \mathrm{PO}_{4}\left(17.5 \mathrm{mg} \mathrm{l}^{-1}\right), \mathrm{MgSO}_{4}\left(17.5 \mathrm{mg} \mathrm{l}^{-1}\right), \mathrm{FeSO}_{4}(10$ $\left.\mathrm{mg} \mathrm{l}^{-1}\right)$, and sodium acetate $\left(225 \mathrm{mg}^{-1}\right)$.

The batch reactors were incubated for 30 days. Samples for MLVSS, soluble microbial products (SMP) and EPS analysis (Section 2.3) were obtained after two weeks of incubation, with three and five sampling events for the batch aerobic/anoxic and anoxic reactors, respectively. Duplicate measurements were performed at each sampling event.

\subsection{Continuous reactors}

To scrutinize the observations in batch tests, further investigations were conducted via two laboratory-scale (5 1 each) SBRs (denoted as $\mathrm{SBR}_{\text {control }}$ and $\mathrm{SBR}_{\mathrm{OSA}}$ ) continuously fed with real wastewater. $\mathrm{SBR}_{\text {control }}$ served as control and was attached to a single-pass aerobic digester, whereas $\mathrm{SBR}_{\mathrm{OSA}}$ was attached to external aerobic/anoxic and anoxic reactors (Section 2.2.2).

\subsubsection{Real wastewater}

Primary effluent (e.g. effluent after primary sedimentation) from Wollongong WWTP was collected weekly and stored at $4{ }^{\circ} \mathrm{C}$ in the dark until used. The wastewater was allowed to reach room temperature prior to feeding to SBRs to avoid temperature shocks.

\subsubsection{Reactor configuration and operation}

The two SBRs (Figure 1) were inoculated with aerobic activated sludge from the Wollongong wastewater treatment plant and operated at 4 cycles/day and an HRT of 12 hours. Each cycle comprised of $15 \mathrm{~min}$ of filling, 5.5 hours of aeration, 1 hour settling, and $15 \mathrm{~min}$ of decanting. The two SBRs were fed from the same influent tank containing real wastewater that was continuously mixed with an impeller. The SRT of $\mathrm{SBR}_{\text {control }}$ and $\mathrm{SBR}_{\mathrm{OSA}}$ was maintained at 10 days by regular sludge wastage $(W)$.

The two SBRs were operated for 87 days with addition of $15 \mathrm{mg} \mathrm{l}^{-1}$ of $\mathrm{FeCl}_{2}$ in the influent tank starting from the $53^{\text {rd }}$ day of operation. Both SBRs had a mixed liquor $\mathrm{pH}$ of 6-8 and dissolved oxygen (DO) concentration of $4-5 \mathrm{mg}^{-1}$. At the $88^{\text {th }}$ day of operation, $\mathrm{SBR}_{\text {control }}$ was attached to a 2-1 aerobic digester to form the "control system" (Figure 1a), and SBR 0 ASA was integrated with an external aerobic/anoxic reactor (2 1) and an anoxic reactor (2 1) to form the "OSA system" (Figure 1b). The aerobic digester and aerobic/anoxic and anoxic reactors were kept at $25^{\circ} \mathrm{C}$ water bath, and continuously mixed by a magnetic stirrer.

[Figure 1 Schematic diagram of the (a) 'control system' consisting of $\mathrm{SBR}_{\text {control }}$ attached to a single-pass aerobic digester and (b) 'OSA system' consisting of SBR $\mathrm{OSA}_{\text {attached to external }}$ aerobic/anoxic (AE/ANX) and anoxic (ANX) reactors.]

The aerobic digester was continuously aerated using an air diffuser placed at the bottom of the reactor (Figure 1a). It was fed with sludge from $\mathrm{SBR}_{\text {control }}$ thickened to $5-10 \mathrm{~g}^{-1}$ by centrifugation for $10 \mathrm{~min}$ at $3,267 \mathrm{xg}\left(Q_{i n}\right)$. The supernatant produced by the thickening step was discarded. Sludge was regularly discharged $\left(Q_{\text {out }}\right)$ to achieve an SRT of 20 days. At steady-state, the aerobic digester had a $\mathrm{pH}$ of 5-7, DO concentration of 4-5 $\mathrm{mg}^{-1}$, and ORP of +180 to $+340 \mathrm{mV}$.

The external aerobic/anoxic reactor was intermittently aerated (e.g., 8/16 hours aeration on/off), and the anoxic reactor was sealed using a silicone-lined cap (shaded area Figure 1b). The combined SRT of the aerobic/anoxic and anoxic reactors was 20 days. Sludge from 
SBR $_{\mathrm{OSA}}$ was thickened to $5-10 \mathrm{~g} \mathrm{l}^{-1}$ by centrifugation for $10 \mathrm{~min}$ at $3,267 \mathrm{xg}$, and then fed to aerobic/anoxic reactor $\left(q_{1}\right)$. The same volume of sludge was removed from the aerobic/anoxic reactor, of which 33\% was transferred from aerobic/anoxic to anoxic $\left(q_{2}\right)$ and the remaining $67 \%$ was discarded $\left(q_{3}\right)$. Accordingly, $16.5 \%$ of sludge was transferred from anoxic to the aerobic/anoxic reactor $\left(q_{4}\right)$ and a further $16.5 \%$ was transferred from anoxic to $\operatorname{SBR}_{\mathrm{OSA}}\left(q_{5}\right)$.

The wasted sludge $\left(\mathrm{q}_{5}\right)$ was thickened to $16-24 \mathrm{~g} \mathrm{l}^{-1}$ by centrifugation for $10 \mathrm{~min}$ at $3,267 \mathrm{xg}$ to obtain the supernatant, which was returned to $\mathrm{SBR}_{\mathrm{OSA}}$. The pellet was discarded. At steady-state, the aerobic/anoxic reactor had a pH of 5-7, DO concentration of less than $1 \mathrm{mg} \mathrm{l}^{-}$ ${ }^{1}$, and ORP of +50 to $+100 \mathrm{mV}$ (measurements obtained when aeration was off), and the anoxic reactor had an ORP range of -400 to $-300 \mathrm{mV}$.

To study the effect of $\mathrm{FeCl}_{2}$ on $\mathrm{OSA}, \mathrm{FeCl}_{2}$ dosing was halted on the $152^{\text {nd }}$ day of operation and then resumed at $30 \mathrm{mg} \mathrm{l}^{-1}$ on the $196^{\text {th }}$ day of operation. It is noteworthy that the background total iron concentration in the wastewater during the period of this study was $1.52 \pm 0.68 \mathrm{mg} \mathrm{l}^{-1}(\mathrm{n}=12)$. Thus even during the period of no $\mathrm{FeCl}_{2}$ dosing, the influent to the SBRs was not completely devoid of iron.

Wastewater and sludge samples were collected twice weekly to monitor reactor performance. There were eight sampling events for SMP and EPS analysis, with duplicate measurements performed at each sampling event.

2.2.3 Calculations of sludge yield and sludge reduction by OSA

To account only for the production of biomass, mixed liquor volatile suspended solids (MLVSS) concentration was used to quantify sludge production instead of mixed liquor suspended solids (MLSS).

The observed sludge yield $\left(Y_{o b s}\right)$ was defined as

$Y_{o b s}=\frac{P}{C}=\frac{g M L V S S}{g C O D}$

Equation 1

where $P$ is the sludge produced and $C$ is the substrate consumed. The experimental $Y_{o b s}$ was derived from the slope of the linear regression of the plot of cumulative sludge produced versus the cumulative substrate consumed. Cumulative values were obtained by incrementing the variations in sludge production and substrate consumption in previous sampling intervals (Chon et al., 2011b).

In this study, sludge yield was presented in two ways. First, the $Y_{o b s}$ of the $\mathrm{SBR}_{\text {control }}$ and $\mathrm{SBR}_{\mathrm{OSA}}$ were compared to understand the difference in MLVSS production by an aerobic reactor receiving anoxic sludge from external reactors relative to a control aerobic reactor (Supplementary Table S1). Second, the sludge yield of the control system (i.e., the $\mathrm{SBR}_{\text {control }}$ and aerobic digester) and OSA system (i.e., $\mathrm{SBR}_{\mathrm{OSA}}$ and external aerobic/anoxic and anoxic reactors) were determined to account for potential MLVSS production in the external reactors as active biomass may consume products of cell lysis (Hao et al., 2010) (Supplementary Table S1).

The sludge reduction achieved by the external aerobic/anoxic and anoxic reactors was calculated using Equation 2: 
Sludge reduction by external reactors $(\%)=\frac{M L V S S_{\text {in }} / M L S S_{\text {in }}-M L V S S_{\text {out }} / M L S S_{\text {out }}}{M L V S S_{\text {in }} / M L S S_{\text {in }}} \times 100$

Equation 2

where $M L V S S_{\text {in }} / M L S S_{\text {in }}$ and $M L V S S_{\text {out }} / M L S S_{\text {out }}$ is the concentration of thickened sludge fed to and wasted from the aerobic/anoxic reactor, respectively.

\subsection{Analytical techniques}

Total suspended solids (TSS) and VSS of influent and effluent and MLSS and MLVSS of sludge were measured according to APHA Standard Method 2540 (Eaton et al., 2005). Sludge volume index (SVI) was measured using $1000 \mathrm{~mL}$ of sludge according to APHA Standard Method 2710-D (Eaton et al., 2005). COD was measured using a Hach DBR200 COD Reactor and a Hach DR/2000 spectrophotometer (program number 430 COD LR) according to US-EPA Standard Method 5220. Total organic carbon (TOC) and total nitrogen (TN) were quantified using a TOC/TN-VCSH analyzer (Shimadzu, Japan). Ammonia $\left(\mathrm{NH}_{3}\right)$ and orthophosphate $\left(\mathrm{PO}_{4}{ }^{3-}\right)$ were measured using flow injection analysis (Lachat instruments, Milwaukee, USA) following APHA Standard Method 4500 (Eaton et al., 2005). Ammonia analysis involved the reaction of ammonia with phenol and hypochlorite to form a blue complex whose colour was intensified by nitroferricyanide, followed by measurement of the absorbance at $630 \mathrm{~nm}$ (APHA 4500-N) (Eaton et al., 2005). Orthophosphate analysis involved the reaction of orthophosphate with ammonium molybdate and antimony potassium tartrate under acidic conditions to form a complex that is reduced by ascorbic acid, followed by measurement of the absorbance at $880 \mathrm{~nm}$ (APHA 4500-P) (Eaton et al., 2005).

Soluble microbial products (SMP) was extracted by centrifuging sludge at $3,267 \mathrm{xg}$ at $4{ }^{\circ} \mathrm{C}$ followed by filtration of supernatant with $0.45 \mu \mathrm{m}$ membrane to ensure removal of suspended solids. EPS was extracted from the same sample by resuspending the pellet in $10 \mathrm{mM} \mathrm{NaCl}$ adjusted to $\mathrm{pH} 10.5$ using $1 \mathrm{M} \mathrm{NaOH}$. The solution was purged with $\mathrm{N}_{2}$ gas, immediately sealed off, and then shaken at $100 \mathrm{rpm}$ at $25^{\circ} \mathrm{C}$. The solution was centrifuged at $3,267 \mathrm{xg}$ at 4 ${ }^{\circ} \mathrm{C}$, and then filtered using $0.45 \mu \mathrm{m}$ membrane to remove suspended solids and obtain EPS extract (Chon et al., 2011a). Proteins and carbohydrates were analysed using the modified Lowry method and phenol-sulphuric method, respectively (Hai et al., 2011; Wijekoon et al. 2013).

To determine the concentration of total iron in sludge, samples were digested according to US EPA Method 3050b that involved digestion using nitric acid and hydrogen peroxide followed by addition of hydrochloric acid (Peña-Icart et al., 2011). The iron concentration of digested samples were measured using an inductively-coupled plasma mass spectrophotometry (Agilent 7500CS, Agilent Technologies, USA).

Two-sample $t$-test was performed using Analysis Toolpak in Microsoft Excel to determine if there was significant difference in the EPS concentrations in the external aerobic/anoxic and anoxic reactors due to $\mathrm{FeCl}_{2}$ dosing. $p<0.05$ was considered to indicate statistical significance.

\section{Results and discussion}

The main part of this study i.e., the continuous operation of the OSA process was carried out with wastewater collected from a municipal wastewater treatment plant. However, the continuous flow experimental program was based on a series of tests conducted with batch reactors fed with a synthetic wastewater. The batch tests were conducted to study the impact 
of $\mathrm{FeCl}_{2}$ addition on MLVSS reduction of the individual reactors of the OSA system (i.e., anoxic/aerobic and anoxic reactors).

\subsection{Impact of $\mathrm{FeCl}_{2}$ addition on batch reactors}

$\mathrm{FeCl}_{2}$ addition to the batch aerobic/anoxic reactor resulted in an increased production of $\mathrm{EPS}_{\text {protein }}$ and lower extent of MLVSS reduction (Table 1). Because the ORP of this reactor varied from +30 to $+80 \mathrm{mV}$, iron prevailed as Fe(III), which decreased the disintegration of the EPS. Changes in the EPS and SMP were primarily observed in the protein fraction due to the preferential binding of $\mathrm{Fe}(\mathrm{III})$ to proteins (Novak et al., 2003). An opposite trend was observed in the batch anoxic reactors (ORP $=-400$ to $-300 \mathrm{mV}$ ), that is, the addition of $\mathrm{FeCl}_{2}$ slightly increased MLVSS reduction and decreased EPS in the form of proteins (Table 1).

[Table 1 MLVSS/MLSS reduction and average EPS and SMP of the batch reactors (average \pm standard deviation; $\mathrm{n}=$ number of measurements).]

Fe(III) can lead to sludge flocculation due to ion bridging and surface charge neutralisation (Higgins and Novak, 1997). In the flocculation process, the outer EPS layer called the "loosely-bound EPS" and the inner EPS layer called the "tightly-bound EPS" are both compressed as flocs aggregate (Niu et al., 2013). Studies report that Fe(III) strongly retains biopolymers within flocs (Murthy and Novak, 2001), and decreases the extractability of the loosely-bound EPS (Niu et al., 2013). However, during anaerobic respiration, Fe(III) can be converted to Fe(II). This results in the release of EPS into solution, especially those in the form of proteins, and eventually to deflocculation (Novak et al., 2003). Park et al. (2006) further suggests that the reduction of $\mathrm{Fe}(\mathrm{III})$ is a prerequisite to the destruction of volatile solids under anaerobic digestion. Thus, in the current study, MLVSS reduction was facilitated in the batch anoxic reactor $(\mathrm{ORP}<-250 \mathrm{mV})$, and not in the batch aerobic/anoxic reactor $(\mathrm{ORP}=+30$ to $+80 \mathrm{mV})$ where bacterial population capable of $\mathrm{Fe}(\mathrm{III})$ reduction may not have been enriched. Indeed, in the presence of $\mathrm{FeCl}_{2}$, the anoxic reactor showed nearly twice as much $\mathrm{EPS}_{\text {protein }}$ in solution (i.e., $\mathrm{SMP}_{\text {protein }}$ ) than the aerobic/anoxic reactor (Table 1), confirming that $\mathrm{Fe}$ (III) reduction (and hence volatile solids reduction) was impaired in intermittently aerated (i.e., aerobic/anoxic) conditions.

The batch reactor investigations systematically demonstrate that aerobic/anoxic treatment of sludge could achieve similar MLVSS reduction as anoxic treatment in the absence of Fe(III). However, if significant (e.g. at least $30 \mathrm{mg}^{-1}$ ) $\mathrm{Fe}(\mathrm{III})$ is present in the sludge, aerobic/anoxic treatment does not effectively reduce volatile solids. These observations form an important baseline for an explanation of the results from OSA operation with real wastewater.

\subsection{Impact of $\mathrm{FeCl}_{2}$ dosing on a continuous $\mathrm{OSA}$ system fed with real wastewater}

\subsubsection{Basic reactor performance and sludge properties}

The COD removal efficiencies of $\mathrm{SBR}_{\text {control }}$ and $\mathrm{SBR}_{\mathrm{OSA}}$ were stable during the start-up phase of the study (Figure 2). After the attachment of the external aerobic/anoxic and anoxic reactors, the COD removal efficiency of $\mathrm{SBR}_{\mathrm{OSA}}$ temporarily decreased probably because it received additional COD from the returned sludge. Nonetheless, $S_{B R}$ OSA quickly acclimatised and from then on, the COD (Figure 2) and TOC (Supplementary Figure S1) removal efficiency of $\mathrm{SBR}_{\text {control }}$ and $\mathrm{SBR}_{\mathrm{OSA}}$ were similar, indicating that OSA had no impact on these parameters.

[Figure $2 \mathrm{COD}$ concentrations and removal by $\mathrm{SBR}_{\text {control }}$ and $\mathrm{SBR}_{\mathrm{OSA}}$ at different $\mathrm{FeCl}_{2}$ dosage.] 
Similar $\mathrm{NH}_{3}-\mathrm{N}$ (Figure 3) and negligible TN (Supplementary Figure S2) removal was observed in the SBRs throughout the operational period. A negligible difference in the $\mathrm{PO}_{4}{ }^{3-}-$ $\mathrm{P}$ removal performance of the SBRs was also observed: $\mathrm{SBR}_{\text {control }}$ and $\mathrm{SBR}_{\mathrm{OSA}}$ had no $\mathrm{PO}_{4}{ }^{3-}$ $\mathrm{P}$ removal up to a $\mathrm{FeCl}_{2}$ dose of $15 \mathrm{mg} \mathrm{l}^{-1}$, and achieved only up to $30 \% \mathrm{PO}_{4}{ }^{3-}-\mathrm{P}$ removal when $\mathrm{FeCl}_{2}$ was added at a concentration of $30 \mathrm{mg} \mathrm{l}^{-1} \mathrm{FeCl}_{2}$ (Figure 3). This was because the $\mathrm{Fe} / \mathrm{P}$ molar ratios (i.e., 1.27 and 0.85 for $\mathrm{FeCl}_{2}$ dosage of $15 \mathrm{mg} \mathrm{l}^{-1}$ and $30 \mathrm{mg} \mathrm{l}^{-1}$, respectively) were lower than the theoretical ratio required for chemical precipitation (e.g., 1.5). Notably, the SVI was below $100 \mathrm{ml} \mathrm{g}^{-1}$ for both SBRs irrespective of iron dosing (Supplementary Figure S3). This indicates that the SBRs possessed rapidly settling flocs (Tchobanoglus et al., 2003), and that OSA did not improve sludge settleability.

[Figure $3 \mathrm{NH}_{3}-\mathrm{N}$ and $\mathrm{PO}_{4}{ }^{3-}-\mathrm{P}$ concentrations in $\mathrm{SBR}_{\text {control }}$ and $\mathrm{SBR}_{\mathrm{OSA}}$ effluent at different $\mathrm{FeCl}_{2}$ dosage.]

The observed negligible impact of OSA on COD (Chudoba et al., 1992; Saby et al., 2003; Goel and Noguera, 2006) and TN (Ye et al., 2008) removal is consistent with the literature. However, an additional aspect revealed in the current study was that fluctuations in influent wastewater strength (COD $=9$ to $\left.133 \mathrm{mg} \mathrm{l}^{-1}, n=41\right)$ similarly affected the COD (Figure 2) removal performance of the control $\mathrm{SBR}_{1}$ and $\mathrm{SBR}_{2}$. This influent COD fluctuation was also observed to somewhat affect the volatile solids reduction capacity of the OSA system (data not shown) although the trend of volatile solids reduction discussed in Section 3.2.2 was consistent.

\subsubsection{Impact of $\mathrm{FeCl}_{2}$ dosing on OSA performance}

The impact of $\mathrm{FeCl}_{2}$ addition on OSA performance in terms of sludge reduction was analysed using $\mathrm{Y}_{\mathrm{obs}}$ (Table 2) derived from the corresponding plots of cumulative sludge produced versus cumulative substrate consumed (Figure 4 and Supplementary Figure S4). Because of the significant variation in the wastewater strength between different runs, comparing the $Y_{o b s}$ values of a reactor at different runs did not give meaningful trends. Therefore, to eliminate interference from the varying influent, the effect of $\mathrm{FeCl}_{2}$ dosage was observed by contrasting the $\mathrm{Y}_{\mathrm{obs}}$ of $\mathrm{SBR}_{1}$ and $\mathrm{SBR}_{2}$ at each experimental phase only (Table 2).

[Figure 4 Cumulative sludge produced (g MLVSS) versus cumulative substrate consumed ( $\mathrm{g}$ $\mathrm{COD}$ ) of $\mathrm{SBR}_{1}$ and $\mathrm{SBR}_{2}$ at different $\mathrm{FeCl}_{2}$ dosage.]

[Table $2 \mathrm{Y}_{\mathrm{obs}}$ of control and OSA system with different dose of $\mathrm{FeCl}_{2}$ to the influent (real wastewater)]

$\mathrm{SBR}_{1}$ and $\mathrm{SBR}_{2}$ had similar $\mathrm{Y}_{\mathrm{obs}}$ during the start-up phase (Table 1). In other words, the SBRs equally acclimatised to wastewater characteristics and operation conditions and the experiments had similar initial conditions.

When 15 and $30 \mathrm{mg} \mathrm{l}^{-1}$ of $\mathrm{FeCl}_{2}$ was added to the influent, the $\mathrm{Y}_{\mathrm{obs}}$ of $\mathrm{SBR}_{\mathrm{OSA}}$ was higher than that of the control $\mathrm{SBR}_{1}$ (Table 1), meaning that the OSA process was unable to reduce the MLVSS production. The $\mathrm{Y}_{\mathrm{obs}}$ of the OSA system (i.e., SBR $\mathrm{OSA}+$ external reactors) was also greater than that of $S B R_{O S A}$, which could indicate that the external reactors had a net MLVSS production. This is supported by the fact that the MLVSS/MLSS reduction of the external reactors was mostly in negative values (Figure 5). On the contrary, without $\mathrm{FeCl}_{2}$ 
addition, the $\mathrm{Y}_{\mathrm{obs}}$ of $\mathrm{SBR}_{\mathrm{OSA}}$ was lower than that of the control $\mathrm{SBR}_{\text {control }}$ by $24.8 \%$ (Table 1), evidencing that OSA reduced the MLVSS production. Furthermore, without $\mathrm{FeCl}_{2}$ dosing, (i) the $\mathrm{Y}_{\mathrm{obs}}$ of the entire OSA system was lower than that of SBR $\mathrm{OSA}$, and (ii) the MLVSS/MLSS ratio of sludge fed to the aerobic/anoxic reactor was reduced (Figure 5).

[Figure 5 Reduction (\%) of MLVSS/MLSS ratio achieved by the external reactors superimposed with the MLVSS/MLSS ratio of the thickened sludge fed to the aerobic/anoxic reactor at different $\mathrm{FeCl}_{2}$ dosage.]

To understand the impact of $\mathrm{FeCl}_{2}$ addition on OSA performance, SMP and EPS profiles of the reactors were investigated (Figure 6a). The difference in the EPS profiles of $\mathrm{SBR}_{\text {control }}$ and $\mathrm{SBR}_{\mathrm{OSA}}$ was not ascertained due to the significant variability of data points in each experimental run (Supplementary Figure S5). Nonetheless, a significant increase in the $\mathrm{EPS}_{\text {protein }}$ of the external aerobic/anoxic reactor (Figure 6) occurred when $\mathrm{FeCl}_{2}$ concentration was changed from zero $\left(33.2 \pm 9.8 \mathrm{mg} \mathrm{g}^{-1}, \mathrm{n}=4\right)$ to $30 \mathrm{mg} \mathrm{l}^{-1}\left(55.7 \pm 10.8 \mathrm{mg} \mathrm{g}^{-1}, \mathrm{n}=5\right)$ (Two sample $t$-test; $t(7)=3.57, p=0.014)$. Correspondingly, $\mathrm{SMP}_{\text {protein }}$ (Figure 6a) and $\mathrm{SMP}_{\text {carbohydrate }}$ (Supplementary Figure S6) of the aerobic/anoxic reactor decreased. These findings suggest that $\mathrm{FeCl}_{2}$ dosing reduced the disintegration of EPS especially in the aerobic/anoxic reactor, and consequently decreased the efficiency of OSA to degrade MLVSS. The deleterious effect of $\mathrm{FeCl}_{2}$ dosing on EPS disintegration and sludge reduction was also observed in the batch aerobic/anoxic reactors (Section 3.1), and was possibly due to the inefficiency of aerobic/anoxic conditions to biologically reduce Fe(III) that bound EPS.

[Figure 6 SMP and iron-associated EPS in the form of proteins of the (a) aerobic/anoxic and (b) anoxic reactors of OSA at zero and $30 \mathrm{mg} \mathrm{l}^{-1} \mathrm{FeCl}_{2}$ dosage.]

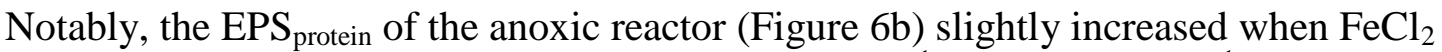
concentration was changed from zero $\left(23.7 \pm 10.0 \mathrm{mg} \mathrm{l}^{-1}, \mathrm{n}=4\right)$ to $30 \mathrm{mg} \mathrm{l}^{-1}\left(34.7 \pm 11.4 \mathrm{mg} \mathrm{l}^{-1}\right.$, $\mathrm{n}=5$ ), but the change was not statistically significant (Two sample $t$-test; $t(7)=1.55, p=0.17$ ).

This indicates that EPS degradation in the anoxic reactor was not as impacted by $\mathrm{FeCl}_{2}$ dosing as the aerobic/anoxic reactor. Nonetheless unlike the batch anoxic reactor (Section 3.1), the external anoxic reactor of the OSA system did not exhibit enhancement of EPS disintegration with $\mathrm{FeCl}_{2}$ dosing. This was probably because the anoxic reactor received less destructible flocs from the aerobic/anoxic reactor, whereas the batch anaerobic reactor stood alone. Moreover, it had a much lower SRT (10 days) than that of the batch anoxic reactors, which was 490 days (calculated from the sludge spent for analysis).

\subsubsection{Mechanisms of sludge reduction in OSA with dual-redox external reactors}

The vulnerability of OSA to $\mathrm{FeCl}_{2}$ dosing belies the critical role that the aerobic/anoxic reactor plays in this particular OSA configuration. The dual-redox external reactor that was utilised in this study is distinct from the OSA configurations reported in literature, which commonly involves a single anoxic or anaerobic external tank (Saby et al., 2003; Goel and Noguera, 2006; Chon et al., 2011b; Coma et al., 2013). Anaerobic condition in OSA (e.g., ORP $=-250$ to $-100 \mathrm{mV}$ ) has been found to improve sludge reduction (Saby et al., 2003). Nonetheless, this study demonstrates that sludge reduction can also occur in intermittently aerated (i.e., aerobic/anoxic) and anoxic conditions that may be easier to implement in fullscale operation (Troiani et al., 2011). However, the volatile solids reduction capacity of this configuration, particularly that of the aerobic/anoxic reactor, is susceptible to iron dosing. 
In the particular OSA configuration investigated in this study, it is possible that the aerobic/anoxic reactor facilitated the hydrolysis of proteins, carbohdyrates, and other macromolecules, thereby enhancing subsequent degradation in the anoxic reactor. The aerobic/anoxic reactor could have also helped ensure that $\mathrm{O}_{2}, \mathrm{NO}_{3}{ }^{-}$, and COD are depleted as much as possible so that the anoxic reactor was deficient of oxygen and substrate. Furthermore, the intermittent aeration in the aerobic/anoxic reactor possibly created alternating redox conditions that could trigger faster biodegradation.

This study confirms that without $\mathrm{FeCl}_{2}$ dosing, the OSA process reduces sludge in two ways: (i) it decreases the MLVSS/MLSS of sludge fed to the external reactors (Figure 5), and (ii) it decreases the sludge yield of the main bioreactor (Table 1). The reduction in volatile solids content of waste sludge may have implications on its treatability and odour reduction during post-processing and transport. The influence exerted by OSA on the biomass growth in the main bioreactor has been reported in earlier studies (Chudoba et al., 1992; Chen et al., 2001; Saby et al., 2003). For example, Chudoba et al. (1992) reported that alternating sludge between favourable and non-favourable growth conditions result in metabolic uncoupling in microorganisms, which forces the biomass that is returned to the main bioreactor to prioritise energy replenishment instead of cellular propagation. The current study provides compelling evidence of lower sludge production in the main bioreactor as a result of the OSA process.

OSA potentially affects biomass growth not only at the cellular level, but also at a microbial community level. Due to sludge interchange, bacteria that are not commonly selected in aerobic conditions may have opportunity to thrive in OSA. For instance, Goel and Noguera (2006) noted an enrichment of slow-growing bacteria such as polyphosphate-accumulating organisms and fermenters in the enhanced biological phosphate removal (EPBR)-SBR due to attachment to an external anaerobic reactor. Aside from having long incubation, fermenters are able to decompose flocs and enhance biomass decay. In a recent study, Ning et al. (2014) found through pyro-sequencing that an anoxic-oxic reactor in an OSA system had more fermentative Sphingobacteria than an anoxic-oxic reactor only. Further investigation on the possible enrichment of slow-growing bacteria and its impact on the $\mathrm{Y}_{\mathrm{obs}}$ will help elucidate the impact of sludge interchange in sludge minimisation.

3.2.3 Verification of the effect of $\mathrm{FeCl}_{2}$ dosing on solids concentration analysis A previous study showed that iron can precipitate as hydrated vivianite $\left(\mathrm{Fe}_{3}\left(\mathrm{PO}_{4}\right)_{2} \cdot 8 \mathrm{H}_{2} \mathrm{O}\right)$ that may cause over-estimation of MLVSS as it loses $17 \%$ of its weight upon incineration at $550{ }^{\circ} \mathrm{C}$ (Tien and Waugh, 1969). Vivianite has been observed in iron-amended anoxic reactors (Frossard et al., 1997). Nonetheless, in the current study, the formation of vivianite in the continuous reactors was unlikely due to the insufficiency of iron in the influent. The average molar $\mathrm{Fe} / \mathrm{P}$ ratio in the influent tank was only 1.27 and 0.85 at the period when $\mathrm{FeCl}_{2}$ concentration was 15 and $30 \mathrm{mg} \mathrm{l}^{-1}$, respectively (Table 3). An et al. (2014) investigated the formation of vivianite in synthetic wastewater with $\mathrm{FeCl}_{2}$ dosing and found that the $\mathrm{Fe} / \mathrm{P}$ molar ratio should be more than 3 to enable significant vivianite formation. The authors attributed this to the partial formation of ferrous hydroxides, which hindered the formation of vivianite.

[Table $3 \mathrm{PO}_{4}{ }^{3-}-\mathrm{P}$ concentration and $\mathrm{Fe} / \mathrm{P}$ molar ratio in the influent at different phases of the experiment.]

[Figure 7 Total Fe concentration of the sludge superimposed with MLVSS/MLSS ratio of $\mathrm{SBR}_{\text {control }}$ and $\mathrm{SBR}_{\mathrm{OSA}}$ at zero and $30 \mathrm{mg}^{-1} \mathrm{FeCl}_{2}$ dosage.] 
It was also observed that the measured Fe concentration, i.e. combined $\mathrm{Fe}(\mathrm{II})$ and $\mathrm{Fe}(\mathrm{III})$, of the sludge of $\mathrm{SBR}_{\mathrm{OSA}}$ steadily increased when $\mathrm{FeCl}_{2}$ dosage was increased from zero to 30 $\mathrm{mg}^{-1}$ due to the accumulation of metal precipitates, whereas that of $\mathrm{SBR}_{\text {control }}$ increased and then decreased (Figure 7). The fluctuation in Fe concentration in $\mathrm{SBR}_{\text {control }}$ was probably due to the wash out of solids. If vivianite had formed and caused over-estimation of MLVSS, the MLVSS/MLSS ratio should have increased when $\mathrm{FeCl}_{2}$ dosage was increased from zero to $30 \mathrm{mg} \mathrm{l}^{-1}$. However, it was observed that the MLVSS/MLSS ratio of SBR OSA $_{\text {decreased and }}$ that of $\mathrm{SBR}_{\text {control }}$ remained the same (Figure 7). This was because the accumulation of metal precipitates in the reactor increased MLSS as observed in other studies (Paul et al., 2001; Li, 2005), but not MLVSS.

\section{Conclusions}

Based on investigations conducted with a continuous flow OSA system receiving real wastewater, this study demonstrated for the first time that the addition of $\mathrm{FeCl}_{2}$ is counterproductive to sludge reduction in the external intermittently aerated (i.e., aerobic/anoxic) reactor. Batch tests showed that $\mathrm{FeCl}_{2}$ dosing decreased the volatile solids reduction of a batch aerobic/anoxic reactor probably due to a decline in the destructibility of EPS. This parallels the findings in continuous OSA operation, wherein it was found that the external aerobic/anoxic reactor had greater EPS and lower SMP when there was $\mathrm{FeCl}_{2}$ dosing. In contrast, $\mathrm{FeCl}_{2}$ did not have any negative effect on sludge reduction of the batch anoxic reactor, and had less severe impact on EPS destruction in the external anoxic reactor during continuous operation. This was probably because anoxic conditions facilitated the biological reduction of $\mathrm{Fe}$ (III) causing deflocculation and eventual sludge degradation. Without $\mathrm{FeCl}_{2}$ addition, the sludge yield of the $\mathrm{SBR}_{\mathrm{OSA}}$ was $24.8 \%$ lower than that of the $\mathrm{SBR}_{\text {control }}$. Results reported here validate two mechanisms of sludge reduction (in absence of iron dosing) by the OSA process: first, the external reactors reduce the volatile solids of waste activated sludge and second, the interchange of sludge decreases volatile solids production in the main bioreactor.

\section{Reference}

An, J.S., Back, Y.J., Kim, K.C., Cha, R., Jeong, T.Y., Chung, H.K., 2014. Optimization for the removal of orthophosphate from aqueous solution by chemical precipitation using ferrous chloride. Environmental Technology 35, 1668-1675.

Chen, G.H., Yip, W.K., Mo, H.K., Liu, Y., 2001. Effect of sludge fasting/feasting on growth of activated sludge cultures. Water Research 35, 1029-1037.

Chon, D.H., Rome, M., Kim, H.S., Park, C., 2011a. Investigating the mechanism of sludge reduction in activated sludge with an anaerobic side-stream reactor. Water Science and Technology 63, 93-99.

Chon, D.H., Rome, M., Kim, Y.M., Park, K.Y., Park, C., 2011b. Investigation of the sludge reduction mechanism in the anaerobic side-stream reactor process using several control biological wastewater treatment processes. Water Research 45, 6021-6029.

Chudoba, P., Morel, A., Capdeville, B., 1992. The case of both energetic uncoupling and metabolic selection of microorganisms in the OSA activated sludge system. Environmental Technology 13, 761770 .

Coma, M., Rovira, S., Canals, J., Colprim, J., 2013. Minimization of sludge production by a sidestream reactor under anoxic conditions in a pilot plant. Bioresource Technology 129, 229-235.

Eaton, A.D., Clesceri, L.S., Greenberg, A.E., 2005. Standard Methods for Examination of Water \& Wastewater, 21 ed. American Public Health Association, Washington DC. 
Foladori, P., Velho, V.F., Costa, R.H.R., Bruni, L., Quaranta, A., Andreottola, G., 2015. Concerning the role of cell lysis-cryptic growth in anaerobic side-stream reactors: The single-cell analysis of viable, dead and lysed bateria. Water Research 74, 132-142.

Frossard, E., Bauer, J.P., Lothe, F., 1997. Evidence of vivianite in FeSO4-flocculated sludges. Water Research 31, 2449-2454.

Goel, R.K., Noguera, D.R., 2006. Evaluation of sludge yield and phosphorus removal in a Cannibal solids reduction process. Journal of Environmental Engineering 132, 1331-1337.

Hai, F.I., Tessmer, K., Nguyen, L.N., Kang, J., Price, W.E., Nghiem, L.D., 2011. Removal of micropollutants by membrane bioreactor under temperature variation. Journal of Membrane Science $383,144-151$.

Hao, X.D., Wang, Q.L., Zhu, J.Y., Van Loosdrecht, M.C.M., 2010. Microbiological Endogenous Processes in Biological Wastewater Treatment Systems. Critical Reviews in Environmental Science and Technology 40, 239-265.

Higgins, M.J., Novak, J.T., 1997. Dewatering and settling of activated sludges: The case for using cation analysis. Water Environment Research 69, 225-232.

Li, J., 2005. Effects of Fe(III) on floc characteristics of activated sludge. Journal of Chemical Technology \& Biotechnology 80, 313-319.

Mishima, I., Nakajima, J., 2009. Control of membrane fouling in membrane bioreactor process by coagulant addition, Water Science and Technology, pp. 1255-1262.

Murthy, S.N., Novak, J.T., 2001. Influence of Cations on Activated-Sludge Effluent Quality. Water Environment Research 73, 30-36.

Navaratna, D., Shu, L., Jegatheesan, V., 2014. Performance of a laboratory-scale membrane bioreactor consisting mixed liquor with aquatic worms under toxic conditions. Bioresource Technology 155, 41-49.

Ning, X., Qiao, W., Zhang, L., Gao, X., 2014. Microbial community in anoxic-oxic-settlinganaerobic sludge reduction process revealed by 454 pyrosequencing analysis. Canadian Journal of Microbiology 60, 799-809.

Niu, M., Zhang, W., Wang, D., Chen, Y., Chen, R., 2013. Correlation of physicochemical properties and sludge dewaterability under chemical conditioning using inorganic coagulants. Bioresource Technology 144, 337-343.

Novak, J.T., Sadler, M.E., Murthy, S.N., 2003. Mechanisms of floc destruction during anaerobic and aerobic digestion and the effect on conditioning and dewatering of biosolids. Water Research 37, 3136-3144.

Park, C., Abu-Orf, M.M., Novak, J.T., 2006. The Digestibility of Waste Activated Sludges. Water Environment Research 78, 59-68.

Paul, E., Laval, M.L., Sperandio, M., 2001. Excess Sludge Production and Costs Due to Phosphorus Removal. Environmental Technology 22, 1363-1371.

Peña-Icart, M., Villanueva Tagle, M.E., Alonso-Hernández, C., Rodríguez Hernández, J., Behar, M., Pomares Alfonso, M.S., 2011. Comparative study of digestion methods EPA 3050B (HNO3-H2O2$\mathrm{HCl}$ ) and ISO 11466.3 (aqua regia) for $\mathrm{Cu}, \mathrm{Ni}$ and $\mathrm{Pb}$ contamination assessment in marine sediments. Marine Environmental Research 72, 60-66.

Saby, S., Djafer, M., Chen, G.-H., 2003. Effect of low ORP in anoxic sludge zone on excess sludge production in oxic-settling-anoxic activated sludge process. Water Research 37, 11-20.

Semblante, G.U., Hai, F.I., Ngo, H.H., Guo, W., You, S.-J., Price, W.E., Nghiem, L.D., 2014. Sludge cycling between aerobic, anoxic and anaerobic regimes to reduce sludge production during wastewater treatment: Performance, mechanisms, and implications. Bioresource Technology 155, 395-409. 
Semblante, G.U., Hai, F.I., Huang, X., Ball, A.S., Price, W.E., Nghiem, L.D., 2015. Trace organic contaminants in biosolids: Impact of conventional wastewater and sludge processing technologies and emerging alternatives. Journal of Hazardous Materials 300, 1-17.

Tchobanoglus, G., Burton, F., Stensel, H., 2003. Wastewater engineering: Treatment and reuse. American Water Works Association, New York.

Tien, P.L., Waugh, T.C., 1969. Thermal and x-ray studies on earth vivianite on Graneros Shale (Upper Cretaceous), Kansas. American Mineralogist 54, 1355-1362.

Troiani, C., Eusebi, A.L., Battistoni, P., 2011. Excess sludge reduction by biological way: From experimental experience to a real full scale application. Bioresource Technology 102, 10352-10358.

Wijekoon, K.C., Hai, F.I., Kang, J., Price, W.E., Guo, W., Ngo, H.H., Nghiem, L.D., 2013. The fate of pharmaceuticals, steroid hormones, phytoestrogens, UV-filters and pesticides during MBR treatment. Bioresource Technology 144, 247-254.

Ye, F.X., Zhu, R.F., Li, Y., 2008. Effect of sludge retention time in sludge holding tank on excess sludge production in the oxic-settling-anoxic (OSA) activated sludge process. Journal of Chemical Technology \& Biotechnology 83, 109-114.

Zhang, A., Li, Y., 2014. Removal of phenolic endocrine disrupting compounds from waste activated sludge using $\mathrm{UV}, \mathrm{H} 2 \mathrm{O} 2$, and $\mathrm{UV} / \mathrm{H} 2 \mathrm{O} 2$ oxidation processes: Effects of reaction conditions and sludge matrix. Science of The Total Environment 493, 307-323. 


\section{LIST OF FIGURES}

Figure 1 Schematic diagram of the (a) control system consisting of $S_{B R} R_{\text {control }}$ attached to a single-pass aerobic digester and (b) OSA system consisting of SBR $\mathrm{OSA}$ attached to external aerobic/anoxic (AE/ANX) and anoxic (ANX) reactors.

Figure 2 COD concentrations of influent and effluent and COD removal by $\mathrm{SBR}_{\text {control }}$ and SBR $\mathrm{OSA}$ at different $\mathrm{FeCl}_{2}$ dosage.

Figure $3 \mathrm{NH}_{3}-\mathrm{N}$ and $\mathrm{PO}_{4}{ }^{3-}-\mathrm{P}$ concentrations of influent and $\mathrm{SBR}_{\text {control }}$ and $\mathrm{SBR}_{\mathrm{OSA}}$ effluent at different $\mathrm{FeCl}_{2}$ dosage.

Figure 4 Cumulative sludge produced (g MLVSS) versus cumulative substrate consumed (g $\mathrm{COD}$ ) of $\mathrm{SBR}_{\text {control }}$ and $\mathrm{SBR}_{\mathrm{OSA}}$ at different $\mathrm{FeCl}_{2}$ dosage.

Figure 5 Reduction (\%) of MLVSS/MLSS ratio achieved by the external reactors superimposed with the MLVSS/MLSS ratio of the thickened sludge fed to the aerobic/anoxic reactor at different $\mathrm{FeCl}_{2}$ dosage.

Figure 6 SMP and iron-associated EPS in the form of proteins of the (a) aerobic/anoxic and (b) anoxic reactors of OSA at zero and $30 \mathrm{mg} \mathrm{l}^{-1} \mathrm{FeCl}_{2}$

Figure 7 Total Fe concentration of the sludge superimposed with MLVSS/MLSS ratio of $\mathrm{SBR}_{\text {control }}$ and $\mathrm{SBR}_{\mathrm{OSA}}$ at zero and $30 \mathrm{mg} \mathrm{l}^{-1} \mathrm{FeCl}_{2}$ 
(a) Control system

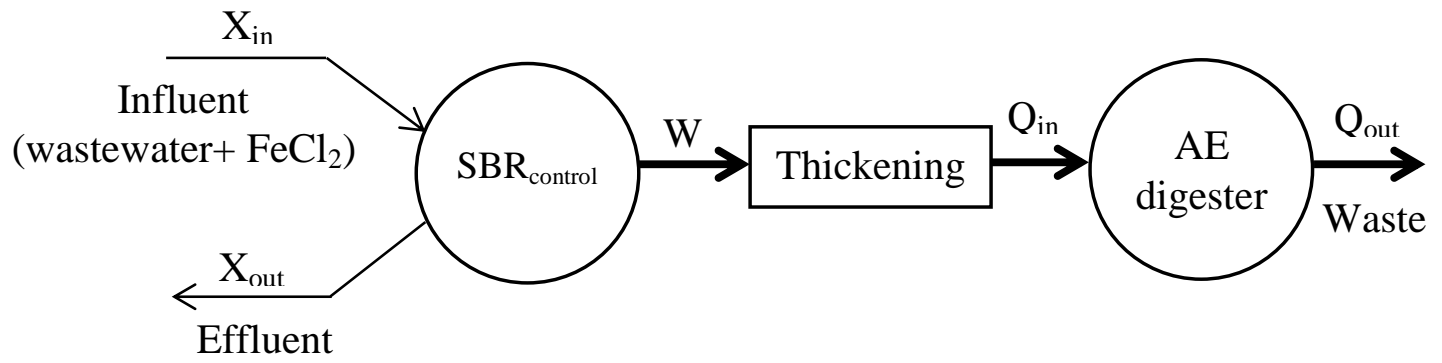

Influent/effluent

Sludge

(b) OSA system

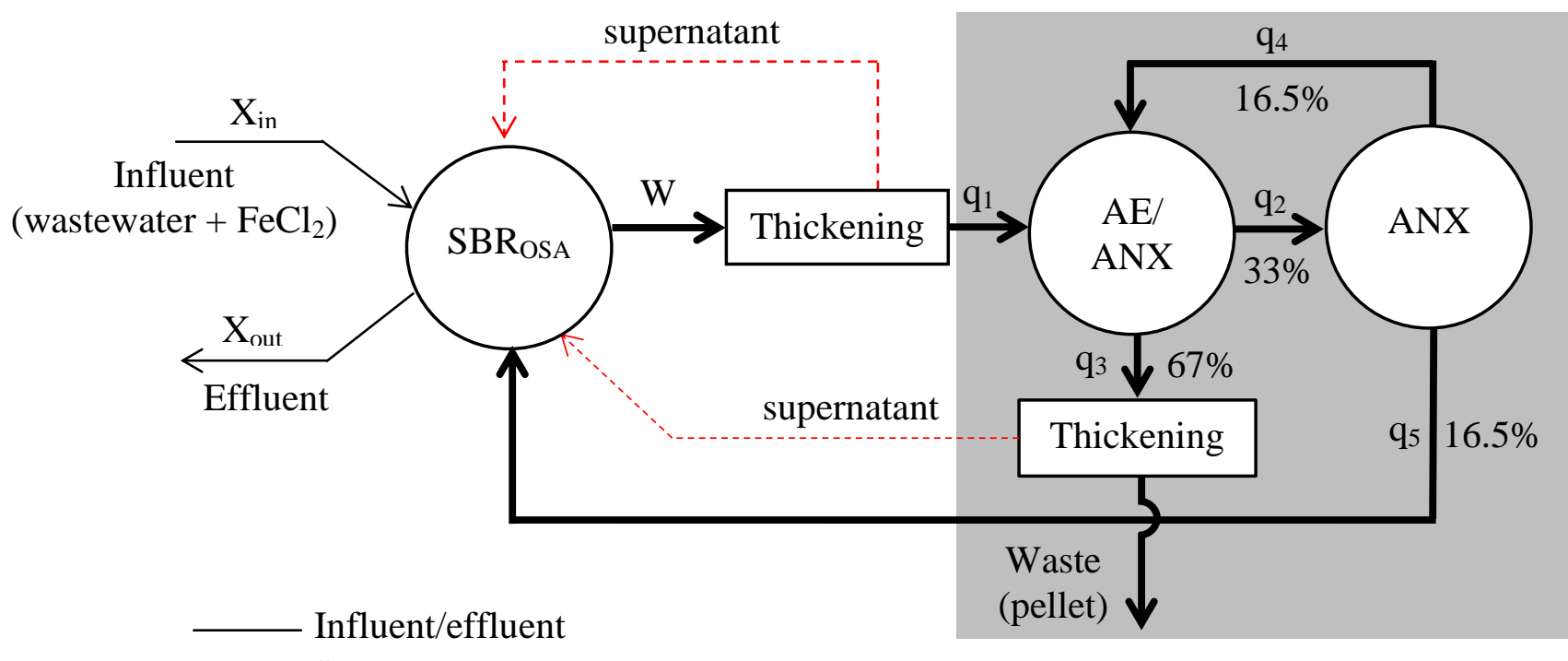

- - - - - Supernatant

Sludge

Figure 1 


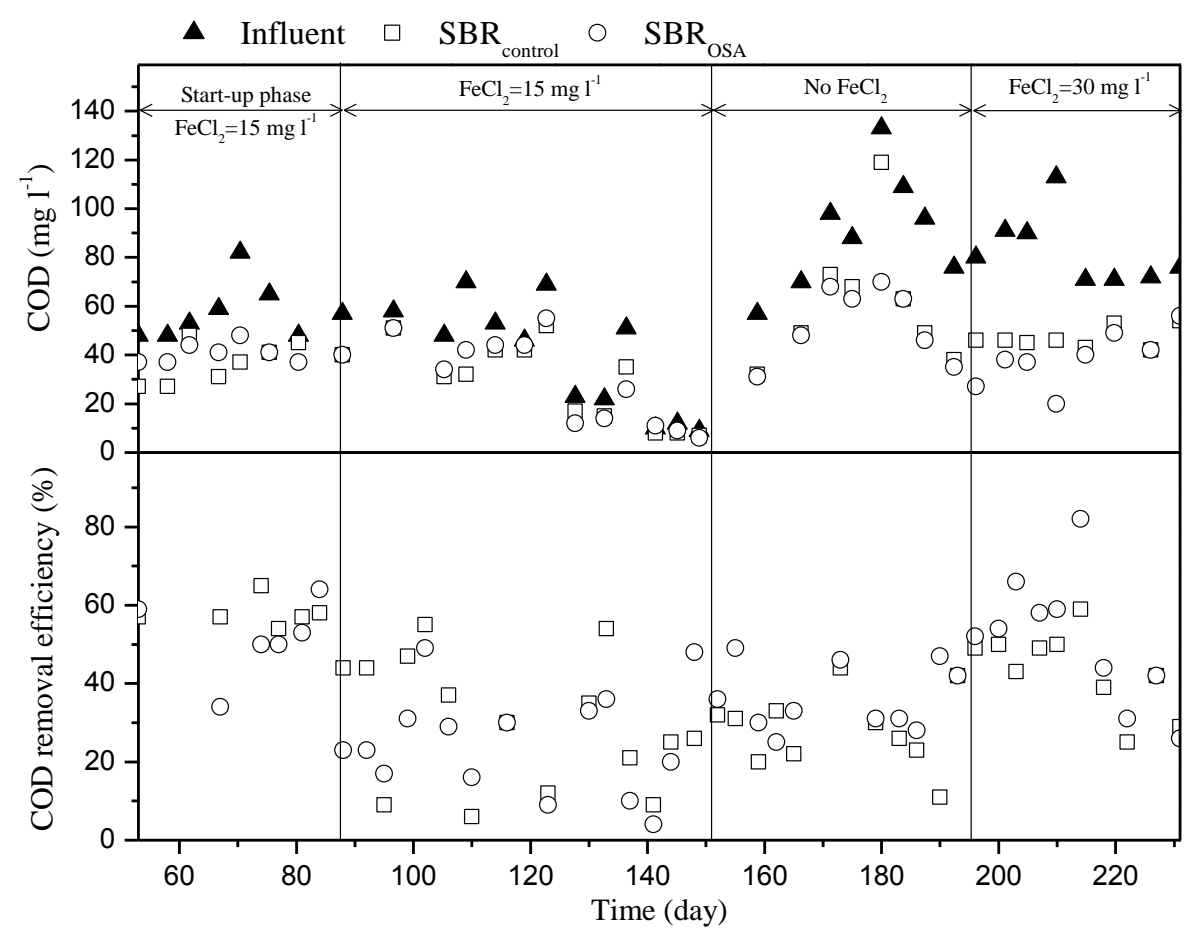

Figure 2

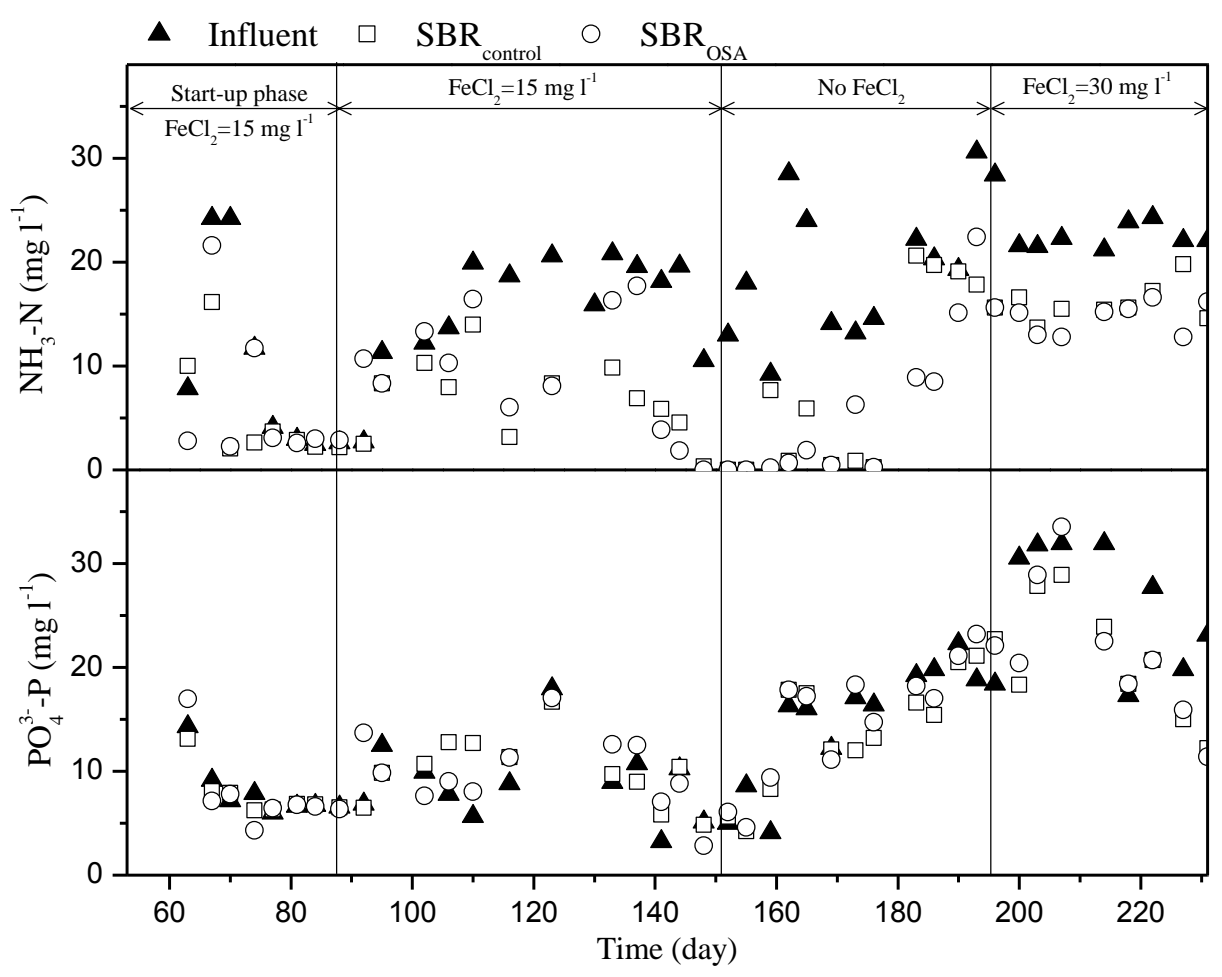

Figure 3 


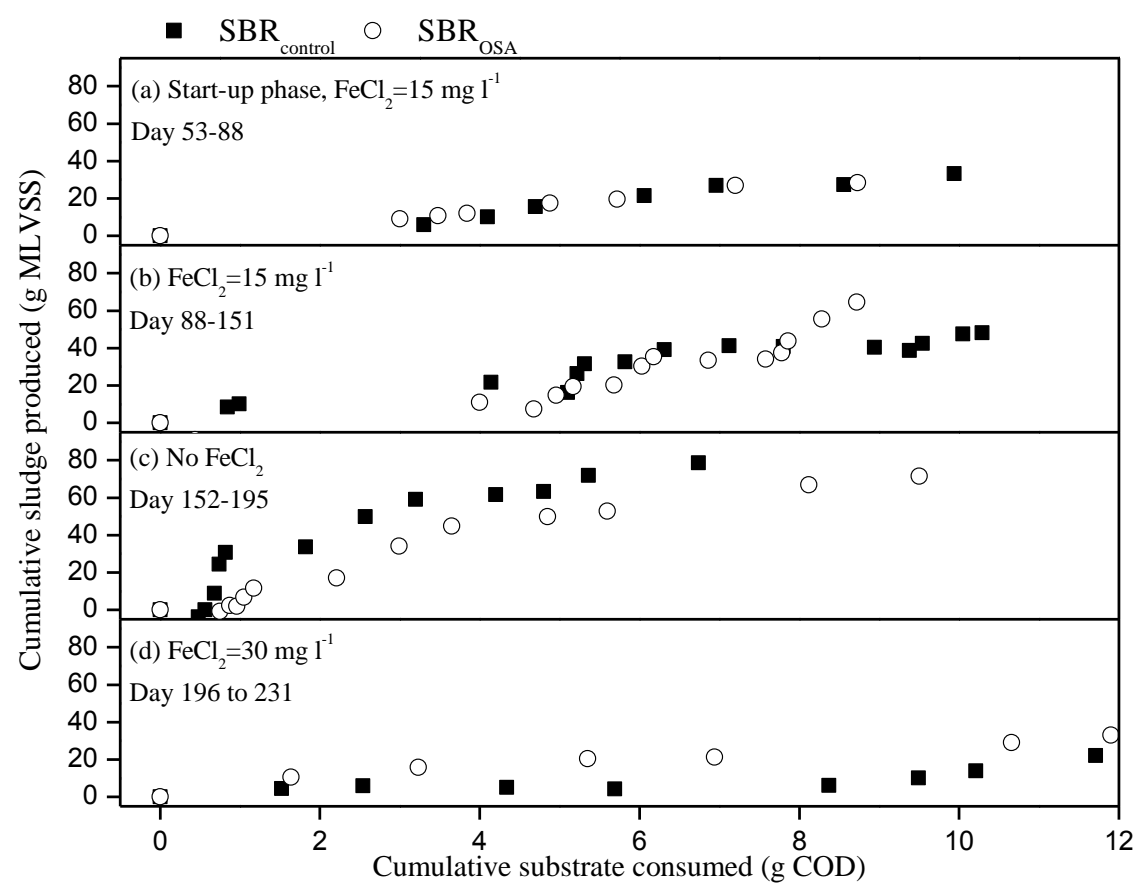

Figure 4

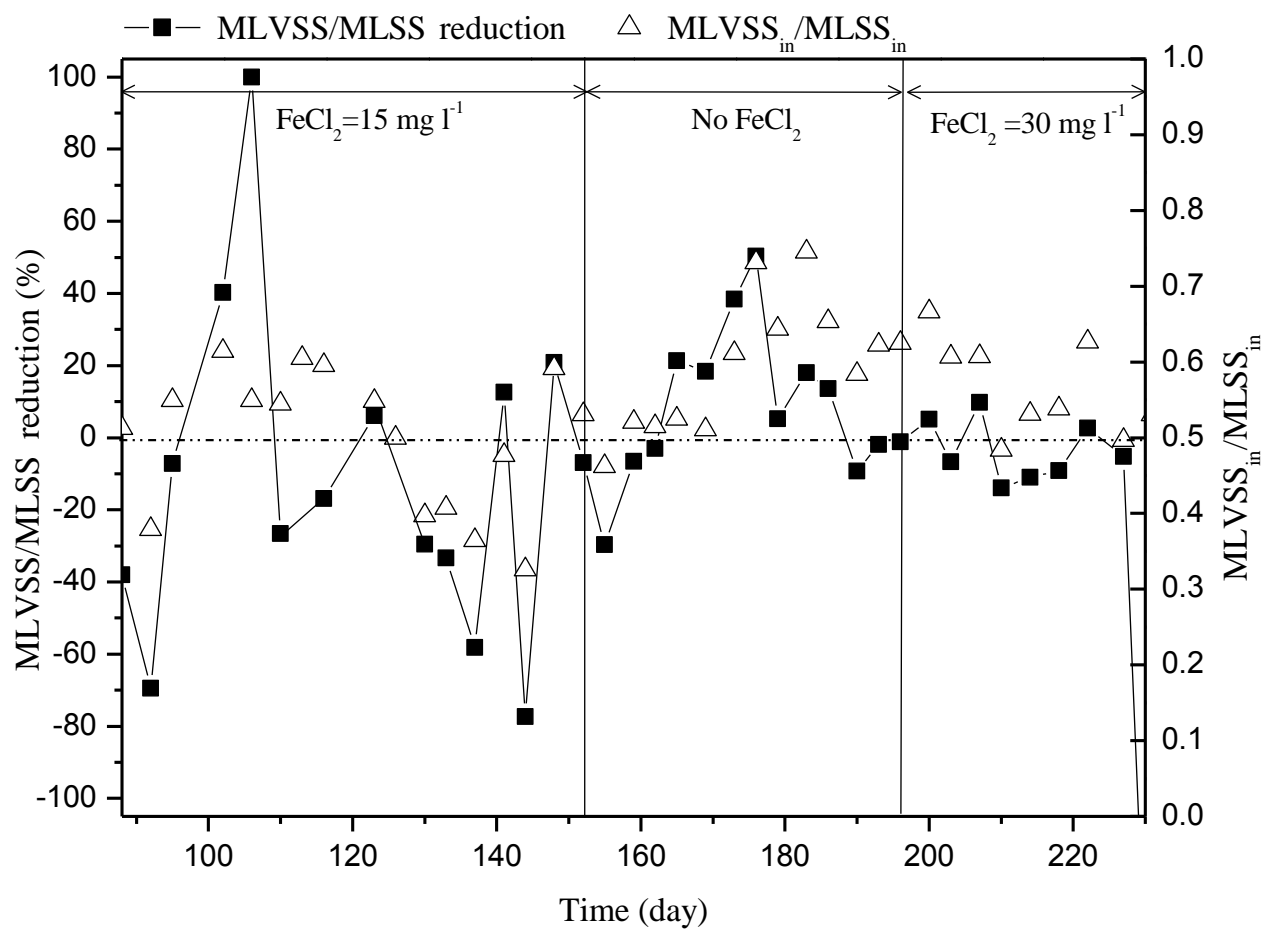

Figure 5 

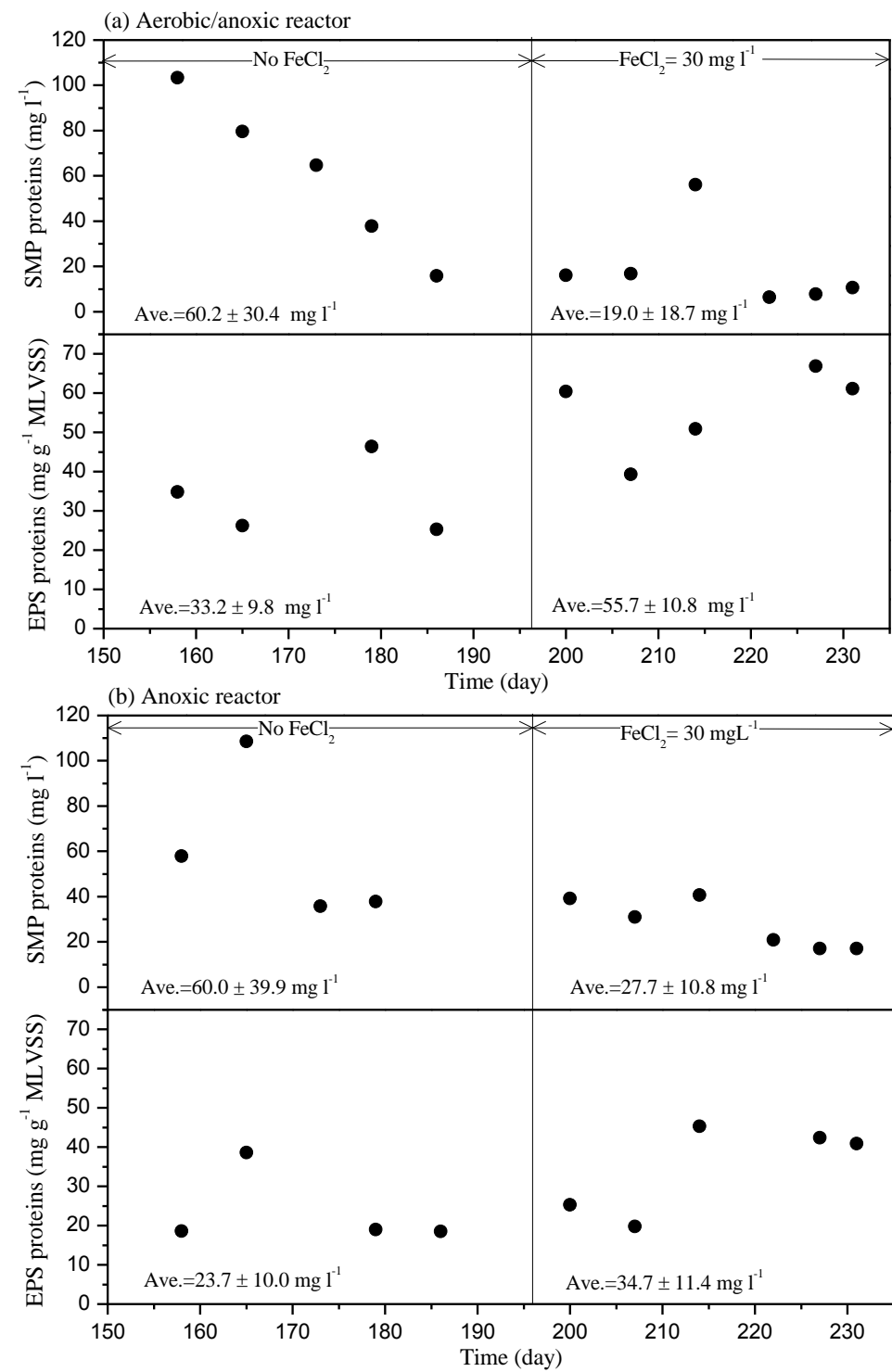

Figure 6 


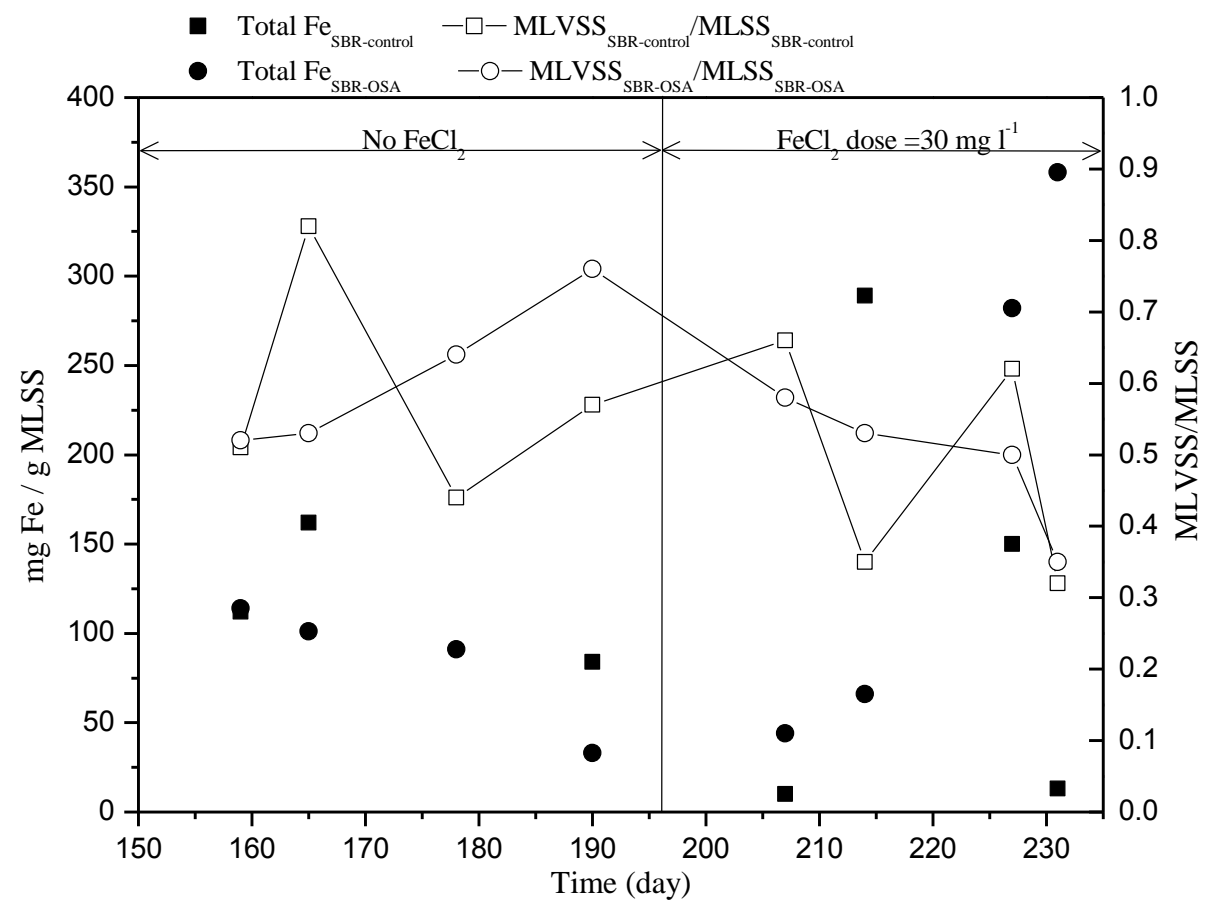

Figure 7 
DOI:10.1016/j.ibiod.2015.07.005

\section{LIST OF TABLES}

Table 1 MLVSS/MLSS reduction and average EPS and SMP of the batch reactors (average \pm standard deviation; $\mathrm{n}=$ number of measurements).

Table $2 \mathrm{Y}_{\mathrm{obs}}$ of control and OSA system with different dose of $\mathrm{FeCl}_{2}$ to the influent (real wastewater).

Table $3 \mathrm{PO}_{4}{ }^{3-}-\mathrm{P}$ concentration and $\mathrm{Fe} / \mathrm{P}$ molar ratio in the influent (real wastewater) at different phases of the experiment. 
Table 1 MLVSS/MLSS reduction and average EPS and SMP of the batch reactors (average \pm standard deviation; $\mathrm{n}=$ number of measurements).

\begin{tabular}{|c|c|c|c|c|c|c|c|c|c|}
\hline \multirow[b]{2}{*}{ Batch reactor } & \multirow[b]{2}{*}{$\begin{array}{l}\text { MLVSS/MLSS } \\
\text { reduction a }{ }^{a}(\%)\end{array}$} & \multicolumn{4}{|c|}{ EPS $^{b}$} & \multicolumn{4}{|c|}{$\mathrm{SMP}^{\mathrm{b}}$} \\
\hline & & $\begin{array}{c}\text { Protein } \\
\left(\mathrm{mg} \mathrm{g}^{-1}\right. \\
\text { MLVSS) }\end{array}$ & $\mathrm{n}$ & $\begin{array}{l}\text { Carbohydrate } \\
\text { (mg g-1 } \\
\text { MLVSS) }\end{array}$ & $\mathrm{n}$ & $\begin{array}{l}\text { Protein } \\
\left(\mathrm{mg} \mathrm{l}^{-1}\right)\end{array}$ & $\mathrm{n}$ & $\begin{array}{l}\text { Carbohydrate } \\
\left(\mathrm{mg} \mathrm{l}^{-1}\right)\end{array}$ & $\mathrm{n}$ \\
\hline aerobic/anoxic & 25 & $5.4 \pm 3.6$ & 5 & $1.0 \pm 0.6$ & 5 & $9.8 \pm 1.6$ & 5 & $6.3 \pm 2.8$ & 5 \\
\hline $\begin{array}{c}\text { aerobic/anoxic } \\
+\mathrm{FeCl}_{2}\end{array}$ & 18 & $10.1 \pm 2.9$ & 5 & $1.3 \pm 0.4$ & 5 & $7.7 \pm 0.7$ & 5 & $14.0 \pm 6.3$ & 5 \\
\hline anoxic & 24 & $21.1 \pm 15.9$ & 3 & $7.3 \pm 4.9$ & 3 & $16.7 \pm 5.8$ & 3 & $18.6 \pm 12.2$ & 3 \\
\hline anoxic $+\mathrm{FeCl}_{2}$ & 29 & $12.8 \pm 8.7$ & 3 & $6.1 \pm 5.1$ & 3 & $30 \pm 11.3$ & 3 & $21.5 \pm 17.4$ & 3 \\
\hline
\end{tabular}

${ }^{\mathrm{a}} \mathrm{MLVSS} / \mathrm{MLSS}$ reduction calculated at Day 30

${ }^{\mathrm{b}}$ Average of measurements obtained from Day 14 to 30

Table $2 \mathrm{Y}_{\mathrm{obs}}$ of control and OSA system with different dose of $\mathrm{FeCl}_{2}$ to the influent (real wastewater).

\begin{tabular}{ccccccccc}
\hline \multirow{2}{*}{$\begin{array}{c}\text { Experimental } \\
\text { phase }\end{array}$} & $\mathrm{SBR}_{\text {control }}$ & $\mathrm{R}^{2}$ & $\begin{array}{c}\text { Control } \\
\text { system }\end{array}$ & $\mathrm{R}^{2}$ & $\mathrm{SBR}_{\text {OSA }}$ & $\mathrm{R}^{2}$ & \begin{tabular}{c} 
OSA system $^{\mathrm{c}}$ \\
\cline { 2 - 9 }
\end{tabular} & $\mathrm{R}^{2}$ \\
\hline $\begin{array}{c}\text { Start-up } \\
\mathrm{FeCl}_{2}= \\
15 \mathrm{mg} \mathrm{l}^{-1}\end{array}$ & 3.61 & 0.94 & - & - & 3.51 & 0.98 & - & - \\
\hline $\begin{array}{c}\mathrm{FeCl}_{2}= \\
15 \mathrm{mg} \mathrm{l}^{-1}\end{array}$ & 4.29 & 0.91 & 3.90 & 0.73 & 7.62 & 0.87 & 9.72 & 0.85 \\
\hline $\mathrm{No} \mathrm{FeCl}_{2}$ & 10.54 & 0.85 & 8.75 & 0.87 & 7.87 & 0.93 & 6.69 & 0.96 \\
\hline $\begin{array}{c}\mathrm{FeCl}_{2}= \\
30 \mathrm{mg} \mathrm{l}^{-1}\end{array}$ & 1.47 & 0.77 & 1.14 & 0.66 & 2.67 & 0.97 & 2.74 & 0.95 \\
\hline
\end{tabular}

\footnotetext{
${ }^{\mathrm{a}}$ Before attaching the external reactors to the SBRs

${ }^{\mathrm{b}}$ Control system consisted of $\mathrm{SBR}_{\text {control }}$ and aerobic digester

${ }^{\mathrm{c}} \mathrm{OSA}$ system consisted of $\mathrm{SBR}_{\mathrm{OSA}}$ and external aerobic/anoxic and anoxic reactors
} 
Table $3 \mathrm{PO}_{4}{ }^{3-}-\mathrm{P}$ concentration and $\mathrm{Fe} / \mathrm{P}$ molar ratio in the influent (real wastewater) at different phases of the experiment.

\begin{tabular}{|c|c|c|c|c|c|c|c|c|}
\hline Experimental phase & $\mathrm{n}$ & $\begin{array}{c}\text { Minimum } \\
\text { influent } \\
\mathrm{PO}_{4}{ }^{3-}-\mathrm{P} \\
\left(\mathrm{mg} \mathrm{l}^{-1}\right) \\
\end{array}$ & $\begin{array}{c}\text { Maximum } \\
\text { influent } \\
\mathrm{PO}_{4}^{3-}-\mathrm{P}(\mathrm{mg} \\
\left.\mathrm{l}^{-1}\right) \\
\end{array}$ & $\begin{array}{c}\text { Average influent } \\
\mathrm{PO}_{4}{ }^{3-}-\mathrm{P} \text { concentration }\left(\mathrm{mg} \mathrm{l}^{-1}\right)\end{array}$ & $\begin{array}{l}\mathrm{PO}_{4}^{3-}-\mathrm{P} \text { standard } \\
\text { deviation }\left(\mathrm{mg} \mathrm{l}^{-1}\right)\end{array}$ & $\begin{array}{c}\text { Minimum } \\
\text { influent } \\
\text { molar } \\
\mathrm{Fe} / \mathrm{P} \\
\end{array}$ & $\begin{array}{c}\text { Maximum } \\
\text { influent } \\
\text { molar } \\
\mathrm{Fe} / \mathrm{P} \\
\end{array}$ & $\begin{array}{c}\text { Average } \\
\text { influent } \\
\text { molar } \\
\mathrm{Fe} / \mathrm{P}\end{array}$ \\
\hline No $\mathrm{FeCl}_{2}$ & 12 & 5.01 & 22.3 & 14.65 & 5.90 & NA & NA & NA \\
\hline $\mathrm{FeCl}_{2}=30 \mathrm{mg} \mathrm{l}^{-1}$ & 10 & 17.30 & 31.90 & 26.23 & 1.71 & 0.69 & 1.28 & 0.85 \\
\hline
\end{tabular}


Effects of iron salt addition on biosolids reduction by oxic-settling-anoxic (OSA) process

\author{
Supplementary Data \\ International Biodeterioration \& Biodegradation
}

Volume 104, October 2015, Pages 391-400

Galilee U. Semblante ${ }^{\mathrm{a}}$, Faisal I. Hai ${ }^{\mathrm{a} *}$, Heriberto Bustamante ${ }^{\mathrm{b}}$, Nelly Guevara ${ }^{\mathrm{b}}$, William E. Price $^{c}$, and Long D. Nghiem ${ }^{\mathrm{a}}$

${ }^{a}$ Strategic Water Infrastructure Laboratory, School of Civil, Mining and Environmental Engineering, University of Wollongong, Wollongong, NSW 2522, Australia

${ }^{\mathrm{b}}$ Sydney Water Corporation, Parramatta, NSW 2124, Australia

${ }^{c}$ Strategic Water Infrastructure Laboratory, School of Chemistry, University of Wollongong, Wollongong, NSW 2522, Australia

* Corresponding author:

Email: faisal@uow.edu.au, Ph +61 242213054

Table S1. Calculation of sludge yield 
The MLVSS produced by $\operatorname{SBR}_{\text {control }}\left(P_{S B R \text {-control }}\right)$ and $\operatorname{SBR}_{\mathrm{OSA}}\left(P_{S B R-O S A}\right)$ at a given time interval were quantified using a mass balance of biomass and shown in Equation S.1 and S.2, respectively:

$$
\begin{aligned}
& P_{S B R-\text { control }}=\Delta M L V S S_{S B R-\text { control }} \times V_{S B R-\text { control }} \times\left(V S S_{e 1} \times X_{\text {out }}+M L V S S_{S B R-\text { control }} \times W-V S S_{i} \times X_{\text {in }}\right) \times \Delta t \\
& P_{S B R-O S A}=\Delta M L V S S_{S B R-O S A} \times V_{S B R-O S A}+\left(V S S_{e 2} \times X_{\text {out }}+M L V S S_{S B R-O S A} \times W-V S S_{i} \times X_{\text {in }}-M L V S S_{A N X} \times q_{5}\right) \times \Delta t
\end{aligned}
$$

where $M L V S S_{\mathrm{SBR}-\text { control, SBR-OSA or ANX }}$ is the biomass concentration of the SBRs and the anoxic reactor, $V_{S B R \text {-control or SBR-OSA }}$ is the effective reactor volume, $V S S_{i}$ is the volatile suspended solids concentration of the influent, $V S S_{\text {el or } e_{2}}$ is volatile suspended solids concentration of the effluent, $X_{\text {in or out }}$ is flow rate of the influent or effluent, $W$ is the flow rate of sludge wasted from the SBRs, $q_{5}$ is the flow rate of sludge returned from the anoxic reactor to $\mathrm{SBR}_{\mathrm{OSA}}$ (Section 2.2), and $t$ is time. Notably, $V S S_{i}$ is deducted from the calculation of $P_{S B R \text {-control }}$ and $P_{S B R-O S A}$ to discount the significant amount of volatile solids carried by real wastewater (e.g. 0.1-0.5 g/L), and $M L V S S_{A N X}$ is deducted from the calculation of $P_{S B R-O S A}$ to discount the biomass that was only recycled back to $\mathrm{SBR}_{\mathrm{OSA}}$ from the anoxic reactor.

Second, the $\mathrm{Y}_{\mathrm{obs}}$ of the control (e.g., combined $\mathrm{SBR}_{\mathrm{control}}$ and aerobic digester) and OSA (e.g., combined $\mathrm{SBR}_{\mathrm{OSA}}$ and external aerobic/anoxic and anoxic reactors) systems were determined. The synthesis of cells in the aerobic digester and external reactors may occur even under limited substrate conditions when microorganisms consume products of cell lysis (Hao et al., 2010), so those reactors may also contribute to MLVSS production of the whole system. The MLVSS production of control $\left(\mathrm{P}_{\text {control }}\right)$ and OSA $\left(\mathrm{P}_{\mathrm{OSA}}\right)$ systems were calculated using Equations S.3 and S.4, respectively:

$$
\begin{aligned}
& P_{\text {control }}=\Delta M L V S S_{S B R-\text { control }} \times V_{S B R-\text { control }}+\Delta M L V S S_{A E} \times V_{A E}+\left(V S S_{e 1} \times X_{o u t}+M L V S S_{A E} \times Q_{\text {out }}\right. \\
& \left.-V S S_{i} \times X_{i n}\right) \times \Delta t \\
& P_{O S A}=\triangle M L V S S_{S B R-O S A} \times V_{S B R-O S A}+\triangle M L V S S_{A E / A N X} \times V_{A E / A N X}+\Delta M L V S S_{A N X} \times V_{A N X}+\left(V S S_{e 2} \times X_{\text {out }}+\right. \\
& \left.M L V S S_{A E / A N X} \times q_{3}-V S S_{i} \times X_{i n}\right) \times \Delta t
\end{aligned}
$$

where $M L V S S_{A E / A N X \text { or } A N X}$ is the biomass concentration of the aerobic/anoxic and anoxic reactors, $V_{A E, A E / A N X}$ or $A N X$ is the effective digester or reactor volume, $Q_{\text {out }}$ is the flow rate of sludge wasted from the aerobic digester, and $q_{3}$ is flow rate of sludge wasted from the aerobic/anoxic reactor. Notably, the sludge interchanged within the external reactors and between $\mathrm{SBR}_{2}$ and the external anoxic reactor were retained in the OSA system hence it is not necessary to deduct those sludge flows from the calculation of $P_{O S A}$.

The amount of substrate consumed $C$ by individual SBRs and the control and OSA systems was calculated according to Equation S.5:

$$
C=\left(C O D_{i}-C O D_{\text {elore } 2}\right) \times X_{\text {in }}
$$

where $\mathrm{COD}_{\mathrm{i}}$ and $\mathrm{COD}_{\mathrm{e} 1 / \mathrm{e} 2}$ are the soluble $\mathrm{COD}$ of the influent and effluent, respectively. 


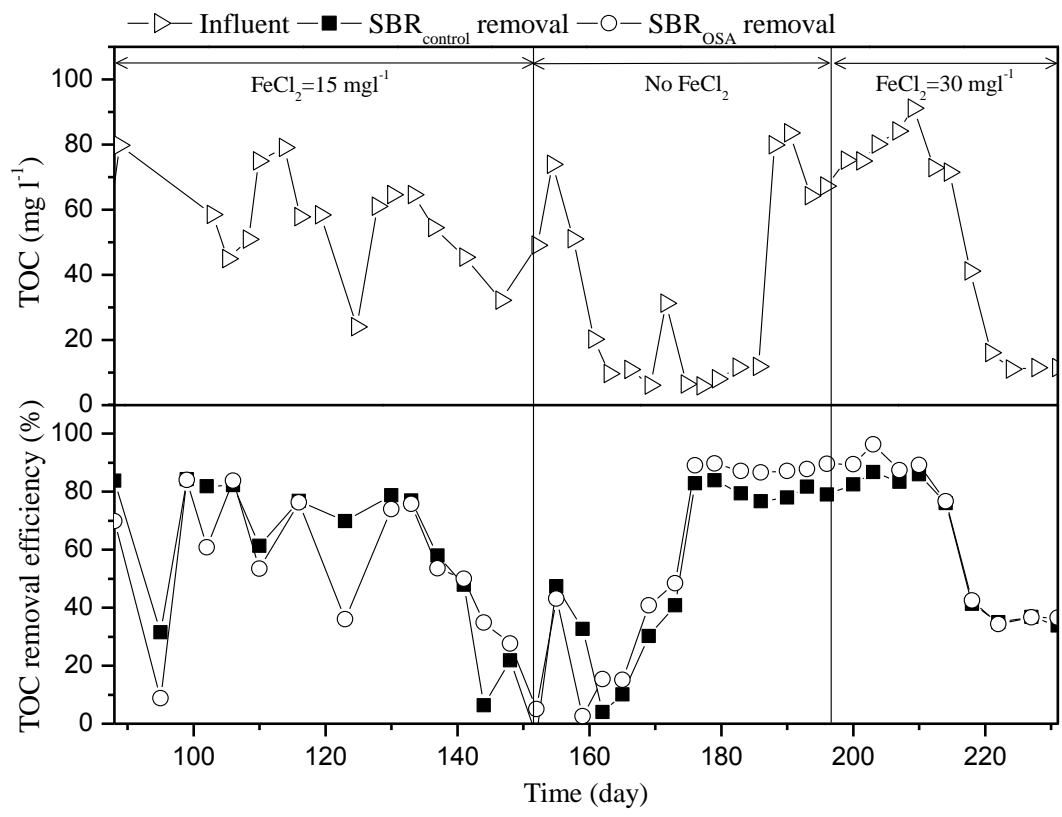

Figure S2. Influent TOC concentration and TOC removal efficiencies of SBR $\mathrm{Sontrol}_{\text {and }}$ $\mathrm{SBR}_{\mathrm{OSA}}$ at different $\mathrm{FeCl}_{2}$ dosage.

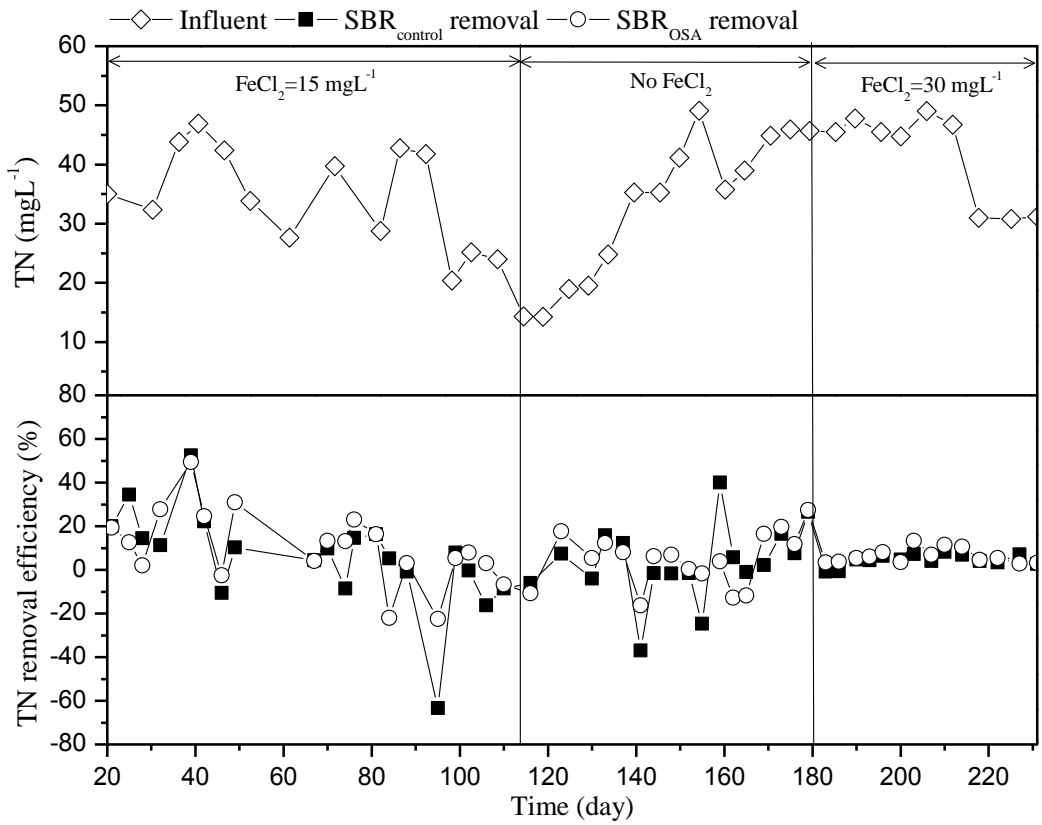

Figure S3. Influent TN concentration and $\mathrm{TN}$ removal efficiencies of $\mathrm{SBR}_{\text {control }}$ and $\mathrm{SBR}_{\mathrm{OSA}}$ at different $\mathrm{FeCl}_{2}$ dosage. 


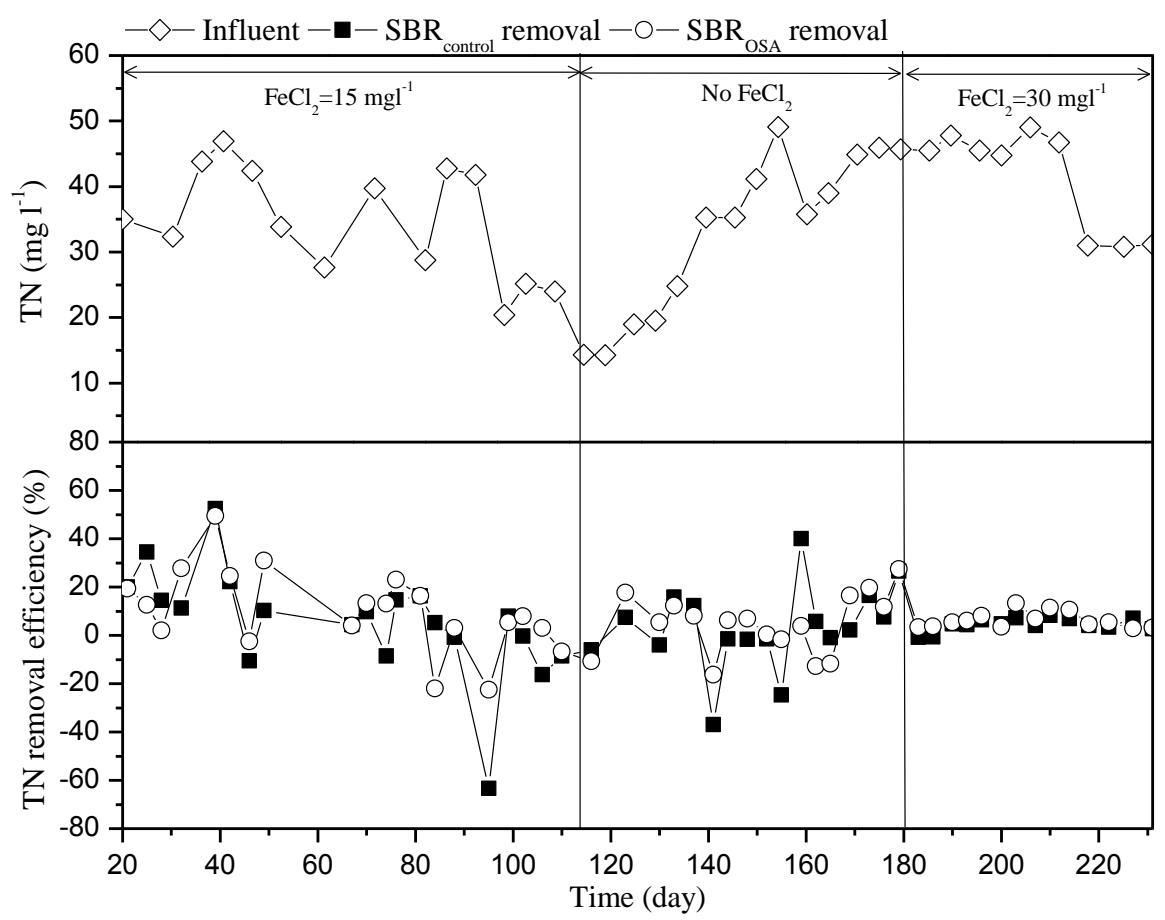

Figure S4. SVI of $\mathrm{SBR}_{\text {control }}$ and $\mathrm{SBR}_{\mathrm{OSA}}$ at different $\mathrm{FeCl}_{2}$ dosage.

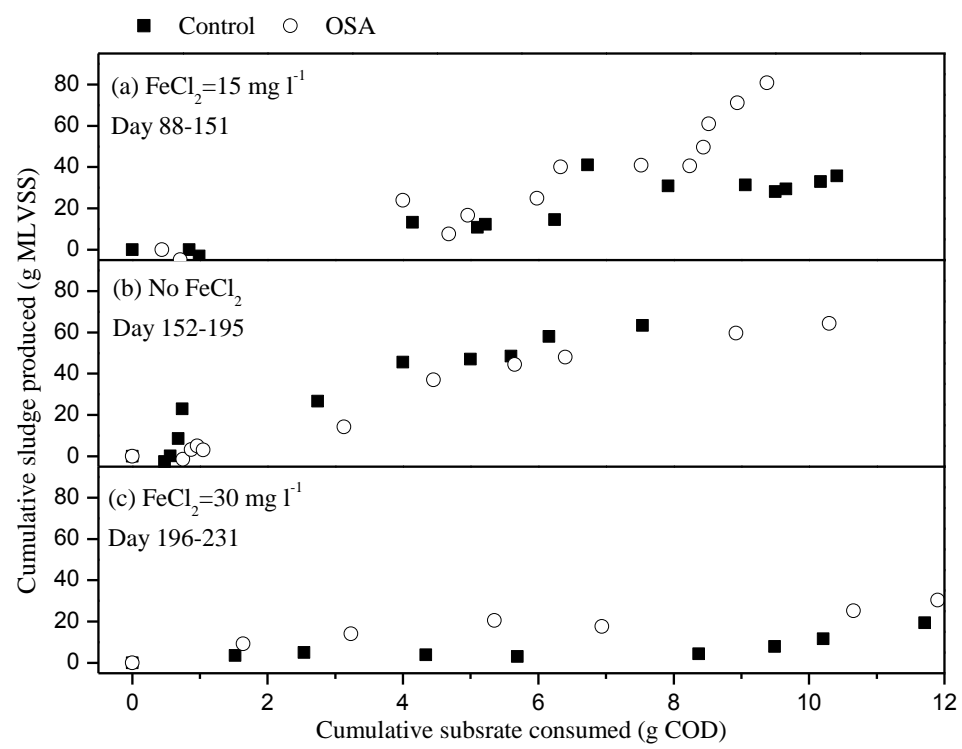

Figure S5. Cumulative sludge produced (g MLVSS) versus cumulative substrate consumed (g $\mathrm{COD}$ ) of the control (e.g., combined $\mathrm{SBR}_{\text {control }}$ and aerobic digester) and OSA (e.g., combined $\mathrm{SBR}_{\mathrm{OSA}}$ and external aerobic/anoxic and anoxic reactors) systems at different $\mathrm{FeCl}_{2}$ dosage. 

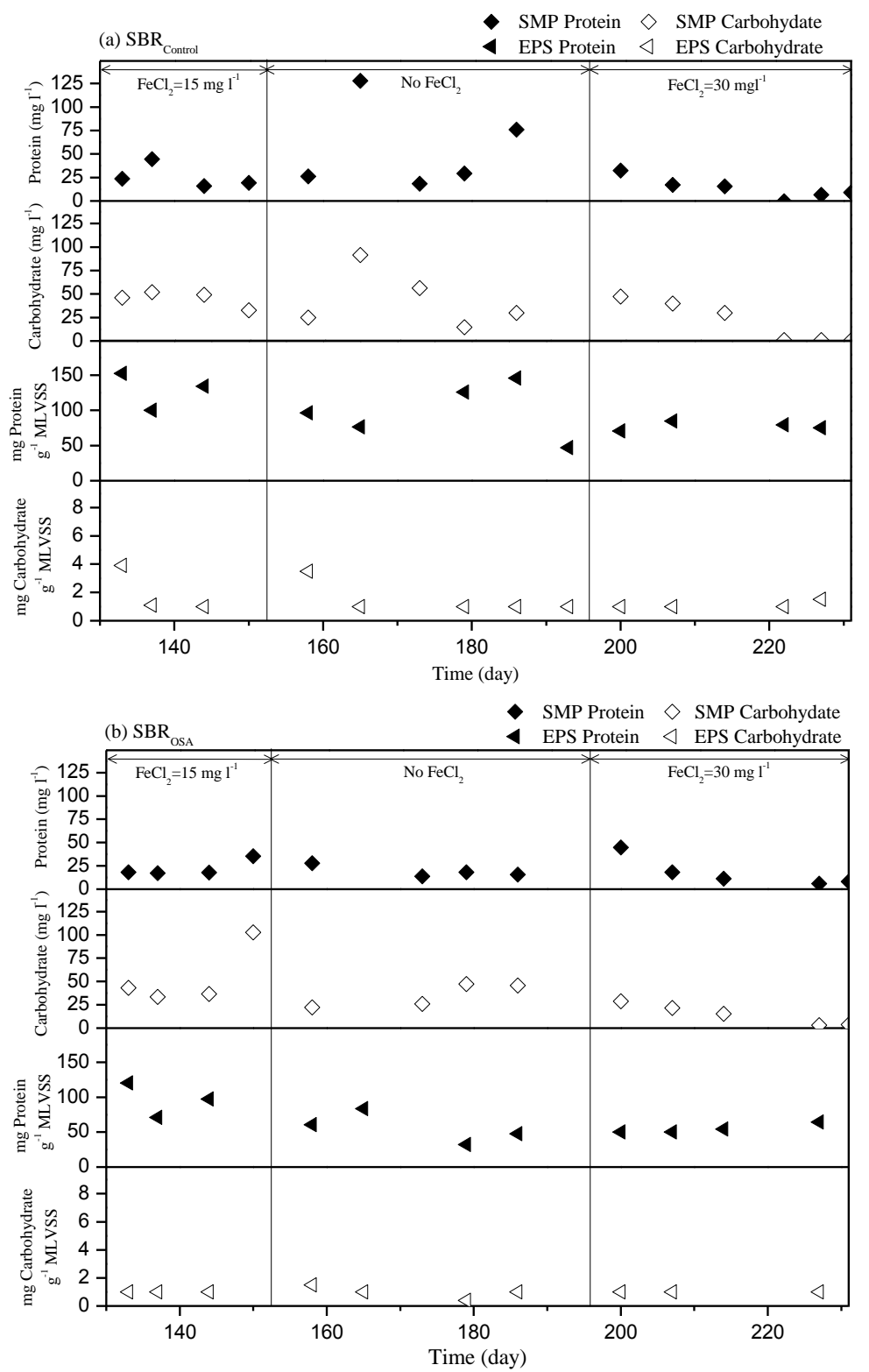

Figure S6. Iron-associated EPS and SMP profiles of $\mathrm{SBR}_{\text {control }}$ (a) and $\mathrm{SBR}_{\mathrm{OSA}}$ (b) at different $\mathrm{FeCl}_{2}$ dosage. 

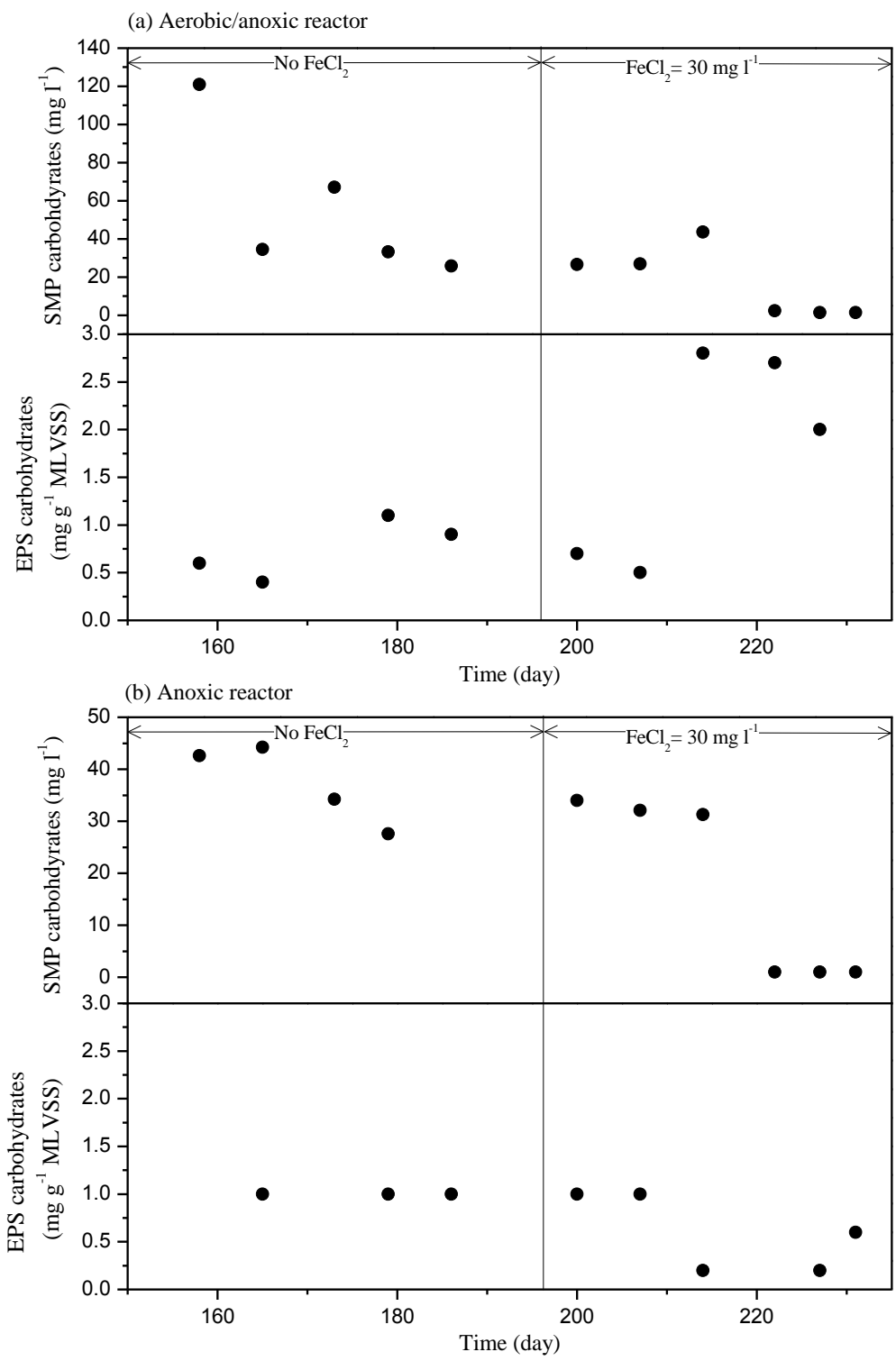

Figure S7. Iron-associated EPS and SMP in the form of carbohydrates of aerobic/anoxic (a) and anoxic (b) reactors at $\mathrm{FeCl}_{2}$ dosage of zero and $30 \mathrm{mg} \mathrm{l}^{-1}$. 